Review

\title{
Commercial Biomass Syngas Fermentation
}

\section{James Daniell, Michael Köpke and Séan Dennis Simpson *}

LanzaTech NZ Ltd., 24 Balfour Road, Parnell, Auckland 1052, New Zealand;

E-Mails: james.daniell@lanzatech.com (J.D.); michael.koepke@lanzatech.com (M.K.)

* Author to whom correspondence should be addressed; E-Mail: sean@lanzatech.com; Tel.: +64-9-304-2100; Fax: +64-9-929-3038.

Received: 3 September 2012; in revised form: 31 October 2012 / Accepted: 5 December 2012 / Published: 19 December 2012

\begin{abstract}
The use of gas fermentation for the production of low carbon biofuels such as ethanol or butanol from lignocellulosic biomass is an area currently undergoing intensive research and development, with the first commercial units expected to commence operation in the near future. In this process, biomass is first converted into carbon monoxide $(\mathrm{CO})$ and hydrogen $\left(\mathrm{H}_{2}\right)$-rich synthesis gas (syngas) via gasification, and subsequently fermented to hydrocarbons by acetogenic bacteria. Several studies have been performed over the last few years to optimise both biomass gasification and syngas fermentation with significant progress being reported in both areas. While challenges associated with the scale-up and operation of this novel process remain, this strategy offers numerous advantages compared with established fermentation and purely thermochemical approaches to biofuel production in terms of feedstock flexibility and production cost. In recent times, metabolic engineering and synthetic biology techniques have been applied to gas fermenting organisms, paving the way for gases to be used as the feedstock for the commercial production of increasingly energy dense fuels and more valuable chemicals.
\end{abstract}

Keywords: biomass; gasification; synthesis gas; syngas; gas fermentation; biofuels; ethanol; butanol; wood-ljungdahl pathway; metabolic engineering; clostridium 


\section{Introduction}

Rising demand for transportation fuels and diminishing reserves of fossil-based fuel sources, coupled with concerns over carbon dioxide $\left(\mathrm{CO}_{2}\right)$ emission-driven climate change have led to a compelling need for new, more sustainable energy sources [1]. Biofuels have been advocated as a promising alternative to the use of fossil resources in the rapidly growing transportation fuels sector [2,3]. Defined as fuels produced from renewable resources such as plant and woody biomass, consumption mandates and fiscal incentives have been enacted to encourage a transition to biofuels [4]. For example, the European Union (EU) Renewable Energy Directive requires that biofuels comprise $10 \%$ of member states' liquid fuels market by 2020 [2]. In the United States, the Energy Independence and Security Act of 2007 mandates the consumption of 35 billion gallons of ethanol-equivalent biofuels by 2022 [3].

While the production of first generation biofuels such as ethanol from corn is mature technology [5], some groups have expressed concerns regarding their environmental, social and economic sustainability, and their limited capacity to provide a solution to both the climate crisis and energy security [5-9]. According to a 2008 Oxfam briefing paper [6], "biofuel policies are deepening poverty and accelerating climate change", a sentiment shared by Greenpeace and the United Nations Food and Agriculture Organisation (FAO) [7-9]. It is argued that first generation biofuels may not be a solution to the climate crisis, as they increase total demand for agricultural land and result in the release of carbon from carbon sinks [10], and lead to rising nitrous oxide emissions through increased use of nitrogen fertilisers $[11,12]$. Furthermore, these production technologies are limited in their ability to provide energy security for the majority of nations. If the entire world supply of carbohydrates was used to produce ethanol a maximum of only $40 \%$ of petrol consumption would be replaced [13]. Finally, there is an increasing appreciation that the production of biofuels should not threaten the availability or affordability of critical resources such as food. Peter Brabeck-Letmathe, the chairman of food-production giant Nestlé, claimed in a Wall Street Journal interview that "world-wide about 18\% of sugar is being used for biofuel today", and that the world's poor are losing access to food as a result [14]. More recently, he argued in an interview with the Swiss newspaper Sonntags Zeitung that politicians should lobby to halt the production of biofuels from food products, and that "producers should use other organic materials" [15]. Certain economists argue that these sugar-based biofuels contribute directly to reduced food security, and that the implementation of biofuel legislation around the world markedly reduces the supply and increases the cost of food, as agricultural land is increasingly used for the cultivation of biofuel crops $[6,16,17]$. These data must, however, be tempered by results that indicate that recent increases in feedstock prices are not strictly the result of biofuel implementation [18].

A further driver for alternative fuels is the volatility of sugar prices, which resulted in a 30 -year high record price of US\$795.40/ton in February 2011 due to crop shortfalls [19]. Nevertheless, there increasingly appears to be a consensus view that while first generation biofuels have played a pivotal role paving the way for an industry dedicated to the production of transport fuels from bio-resources, and establishing the benefits of such an approach in the minds of the public and governments globally, new routes for biofuel production must be developed $[12,18,20]$. 
Consequently, while food crops such as sugarcane or corn remain the dominant feedstock for biofuel production, a second generation of biofuel production technologies that utilise energy-dense lignocellulosic biomass is under development. These technologies seek to overcome the chief limitation of first generation feedstocks by avoiding the use of food crops and arable land for fuel production. For example, indigenous lignocellulosic woody and grass species which are well adapted to local environments, like switchgrass in the United States, can be utilised [20]. Furthermore, lignocellulosic biomass can be sourced from waste products such as forestry residues. Although these second-generation biofuels may still compete with food for other agricultural inputs such as water, and could potentially continue to threaten food security, technologies that do not use extensive monocultures will likely not pose this problem [6]. In fact, polyculture feedstocks such as low-input high-diversity grasslands has been shown to provide superior bioenergy yields than monocultures [21]. According to a report commissioned by the United States Department of Energy (DOE) and the Department of Agriculture (USDA), forestland and agricultural land could account for 1.3 billion dry tons per year of lignocellulosic biomass in the US, enough to meet one third of the country's current demand for transportation fuels [22]. The technical potential for biomass energy is estimated at up to 1500 EJ per year [23], with around 250 EJ per year considered available on a sustainable basis [24]. It is predicted that by 2020 first generation biofuels will remain dominant [20]; however, their intrinsic limitations have led to experts arguing that second-generation biofuels will inevitably become the primary route to biofuel production $[5,20,25]$.

This article explores gas fermentation, one of three major approaches to the production of second generation biofuels from lignocellulosic biomass. In the context of gas fermentation, lignocellulosic biomass such as forestry crops, perennial grasses and agricultural residues can be gasified to carbon monoxide ( $\mathrm{CO}$ ) and hydrogen $\left(\mathrm{H}_{2}\right)$-rich synthesis gas (syngas), which is then fermented by acetogenic organisms to produce hydrocarbons that can be used as a fuel or chemical feedstock. Two other key second generation approaches are the thermochemical Fischer-Tropsch (FT) process, where a metal catalyst is used to convert generated syngas to liquid fuels, and biochemical lignocellulosic fermentation, where components of lignocellulosic biomass are either directly or after pre-treatment fermented to fuels. These two other technologies are currently the focus of the majority of second generation biofuel research and development; in Europe the majority of demonstration projects utilise the biochemical route, while in North America both of these routes are being pursued [26]. Gas fermentation combines strategies from both approaches and in this sense can be considered a hybrid [27,28].

\section{Advantages of Gas Fermentation}

Gas fermentation has a fundamental advantage over first generation technologies as it allows the use of non-food biomass with sufficient feedstock availability to produce substantial volumes of an environmentally sustainable fuel. Additionally, gas fermentation offers numerous process advantages compared with other second-generation approaches in terms of feedstock flexibility and production economics. Gas fermentation has tremendous feedstock flexibility and high rates of energy and carbon capture. In addition, the selectivity, process robustness, catalyst flexibility, and development potential are high [29,30]. 
The Fischer-Tropsch (FT) process uses a metal catalyst such as iron or cobalt to thermochemically convert syngas into liquid hydrocarbons [31]. Like gas fermentation, this process begins with the gasification of biomass into synthesis gas, which is extensively cleaned and compositionally optimised through an energy intense water-gas shift step. This treated syngas is then converted to a mixture of hydrocarbons through the FT process, which are hydrocracked to produce liquid fuels [32]. Several detailed schemes have been proposed to describe the reaction mechanism of the FT process $[31,33,34]$. Invented by Franz Fischer and Hans Tropsch in the 1920s [35], the FT process has undergone considerable development and is used at large scale in South Africa for the conversion of coal to liquid fuels [31]. More recently it has been proposed that the FT process be used with lignocellulosic biomass as a feedstock, although this has yet to be achieved on a commercial scale [25,32]. Like gas fermentation, the FT process has the key advantage of feedstock flexibility as a result of the gasification step, which allows all of the biomass, including lignin, to be accessed.

Limitations in the robustness, flexibility and selectivity of the metal catalysts used in the FT process are thought to result in a production cost disadvantage when compared with gas fermentation [36]. High levels of syngas purity are required to prevent catalyst poisoning; for example, the presence of certain chemical species in the syngas such as sulphur or $\mathrm{CO}_{2}$ may interfere with, or permanently deactivate the catalysts used [37]. Furthermore, a fixed ratio of gases within the syngas is often required to ensure maximum productivity. For example, cobalt-based FT catalysts require a consistent $\mathrm{H}_{2}$ :CO ratio of about 2.15 [31]. This is particularly challenging to achieve with a non-uniform feedstock such as biomass or municipal solid waste (MSW). These strict requirements consequently mean that the production of purified, compositionally optimal syngas accounts for $60 \%-70 \%$ of the operating costs of a traditional FT plant [31]. By contrast, biological catalysts can process a broad range of syngas component ratios, negating the need for an external gas shift operation [38], and are far more tolerant to contaminants in the syngas, requiring a less expensive gasification process [39]. Additionally, FT catalysts have a lower selectivity than biological catalysts, with the typical selectivity of around $45 \%$ resulting in a range of undesired by-products [27]. The higher selectivity of biological catalysts means that gas fermentation has higher yields and simplified downstream processing, with a reduced incidence of undesired by-products [30,36]. Furthermore, the FT process requires a high temperature and reactors highly pressured to over $7 \mathrm{MPa}$, both of which increase capital and operating costs [27]. Finally, the metal catalysts involved in the FT process can be very expensive [37], while gas fermenting bacteria effectively regenerate themselves using a fraction of the available feed gas and supplemented growth media which is of low cost

Published studies comparing FT processes and gas fermentation for ethanol production indicate that gas fermentation has greater fuel yield and energy efficiency [36]. Griffin and Schultz compared the conversion of woody biomass syngas to ethanol via the two technologies [36]. The results indicated that the FT process has a relative overall energy efficiency of $45 \%$, while gas fermentation has an overall energy efficiency of $57 \%$, in terms of energy in feedstock converted to final product [36]. Furthermore, in the production of ethanol from biomass, gas fermentation has lower carbon dioxide emissions and a higher rate of carbon conversion to fuel when compared with the thermochemical route [36]. The nature of the metal catalyst is a fundamental limitation in the FT process, and although recent research into the use of colloidal cobalt and iron nanoparticles demonstrates a route to improved 
activity and selectivity [40], microbial catalysts used in gas fermentation remain far more robust and selective.

Lignocellulosic fermentation is a multi-step process where lignocellulosic biomass is pre-treated and then hydrolysed in order to convert the carbohydrate polymers cellulose and hemicellulose to monomeric sugars, which are fermented to produce ethanol [41]. It has been predicted that lignocellulosic fermentation will partially replace first generation fermentation technologies for bioethanol production within the next decade [26].

However, a key challenge for biochemical lignocellulosic fermentation is the recalcitrance of biomass. Lignocellulosic fermentation cannot directly utilise the lignin fraction which typically makes up $10 \%-25 \%$ of biomass. This is significant, as the lignin accounts for $25 \%-35 \%$ of the energy content of the feedstock. To allow fermentation of the carbohydrate fraction of this resource, lignin must be separated from cellulose and hemicellulose polymers via a complex and costly pre-treatment process so that these polymers may be broken down into fermentable sugars by enzymatic hydrolysis [41]. Methods used for pre-treatment include physical treatments such as milling and irradiation as well as chemical treatments such as the use of oxidising agents and strong acids $[42,43]$.

In gas fermentation, most of these steps are unnecessary and replaced by the gasification process, which allows the entire feedstock (both the lignin and carbohydrate portions) to be converted to a fermentable syngas [29]. The unifying nature of gasification allows heterogeneous resources to be processed through a single technology for the production of a fermentable gas stream. Conversely, biochemical pre-treatments are far less accepting of diverse inputs, and must be calibrated for a homogenous or defined stream of feedstock [44]. Although work into consolidated bioprocessing (CBP) where cellulolytic bacteria convert lignocellulose in one step has shown promise [45], standard lignocellulosic fermentation is far closer to commercial viability.

Table 1 provides a comparison between standard first generation, lignocellulosic fermentation, the thermochemical FT process, and gas fermentation technologies for biofuel production. The perceived technical advantages offered by gas fermentation may allow a production cost advantage over other second generation biofuels in terms of both operating and capital costs. Furthermore, the microbial catalysts used in gas fermentation are now becoming the focus of molecular biology investigation and genetic modification technologies [46], which offer tremendous scope for improvement in both product value and process performance, as discussed in Section 7. 
Table 1. Comparison between first generation, and second generation biochemical, thermochemical and gas fermentation biomass-to-biofuel technologies.

\begin{tabular}{|c|c|c|c|c|}
\hline & \multirow{2}{*}{$\begin{array}{l}\text { First generation } \\
\begin{array}{l}\text { Corn ethanol } \\
\text { (yeast fermentation) }\end{array}\end{array}$} & \multicolumn{3}{|l|}{ Second generation } \\
\hline & & $\begin{array}{l}\text { Biochemical } \\
\text { (lignocellulosic fermentation) }\end{array}$ & $\begin{array}{l}\text { Thermochemical } \\
\text { (Fischer-Tropsch process) }\end{array}$ & $\begin{array}{l}\text { Gas fermentation } \\
\text { (hybrid process) }\end{array}$ \\
\hline \multicolumn{5}{|c|}{ State of the art and political implications } \\
\hline $\begin{array}{l}\text { Current state of } \\
\text { the technology }\end{array}$ & $\begin{array}{l}\text { Commercially established } \\
\text { Mature technology producing large } \\
\text { quantities of fuel on a commercial } \\
\text { scale [5]. The most energy efficient } \\
\text { biofuel production technology to date [47]. }\end{array}$ & $\begin{array}{l}\text { Pre-commercial } \\
\text { Demonstration and commercial plants in } \\
\text { operation [48]. Predicted to partially replace } \\
\text { first generation bioethanol technologies } \\
\text { within the next decade [26]. }\end{array}$ & $\begin{array}{l}\text { Pre-commercial } \\
\text { Technology highly established with coal } \\
\text { feedstock. Biomass synthesis gas pilot plants } \\
\text { in operation with commercial plants } \\
\text { planned [48]. }\end{array}$ & $\begin{array}{l}\text { Pre-commercial } \\
\text { Semi-commercial demonstration plants in } \\
\text { operation [49]. }\end{array}$ \\
\hline Energy security & $\begin{array}{l}\text { Low } \\
\text { Limited feedstock potential [12]. }\end{array}$ & $\begin{array}{l}\text { Variable } \\
\text { Uniform feedstock requirement may limit } \\
\text { feedstock potential }[6,22] .\end{array}$ & $\begin{array}{l}\text { High } \\
\text { Large feedstock potential [22], including non- } \\
\text { biomass sources such as industrial waste gas } \\
\text { streams. }\end{array}$ & $\begin{array}{l}\text { High } \\
\text { Large feedstock potential [22], including } \\
\text { non-biomass sources such as industrial } \\
\text { waste gas streams [50]. }\end{array}$ \\
\hline Food security & $\begin{array}{l}\text { Poor } \\
\text { Feedstock competes directly with food } \\
\text { crops [6]. }\end{array}$ & $\begin{array}{l}\text { Variable } \\
\text { Feedstock does not compete directly with } \\
\text { food crops but could require extensive } \\
\text { monocultures, thus competing for agricultural } \\
\text { inputs [6]. }\end{array}$ & $\begin{array}{l}\text { High } \\
\text { Feedstock does not compete directly with } \\
\text { food crops. } \\
\end{array}$ & $\begin{array}{l}\text { High } \\
\text { Feedstock does not compete directly with } \\
\text { food crops. }\end{array}$ \\
\hline \multicolumn{5}{|l|}{ Overall efficiency } \\
\hline Energy capture & $\begin{array}{l}\text { High } \\
\text { All energy in sugar can be captured } \\
\text { through fermentation. Energy-intensive } \\
\text { distillation of ethanol from fermentation } \\
\text { broth [12]. }\end{array}$ & $\begin{array}{l}\text { Poor } \\
\text { Energy and carbon in lignin cannot be } \\
\text { captured [41]. Significant process energy loss } \\
\text { in converting lignocelluloses into fermentable } \\
\text { sugars [51] }\end{array}$ & $\begin{array}{l}\text { High } \\
\text { Energy and carbon in both lignin and } \\
\text { cellulosic fractions of biomass are converted } \\
\text { to syngas by gasification. Gasification energy } \\
\text { efficiency is approximately } 75 \%-80 \% \\
\text { depending on the carbon, moisture and ash } \\
\text { content of the biomass feedstock [52]. Overall } \\
\text { plant energy efficiency (energy in feedstock } \\
\text { converted to final product) of } 45 \% \text { [36]. }\end{array}$ & $\begin{array}{l}\text { High } \\
\text { Energy and carbon in both lignin and } \\
\text { cellulosic fractions of biomass are converted } \\
\text { to syngas by gasification. Gasification } \\
\text { energy efficiency is approximately } \\
75 \%-80 \% \text { depending on the carbon, } \\
\text { moisture and ash content of the biomass } \\
\text { feedstock [52]. Overall plant energy } \\
\text { efficiency (energy in feedstock converted to } \\
\text { final product) of } 57 \% \text { [36]. }\end{array}$ \\
\hline
\end{tabular}


Table 1. Cont.

\begin{tabular}{|c|c|c|c|c|}
\hline & \multirow{2}{*}{$\begin{array}{l}\text { First generation } \\
\text { Corn ethanol } \\
\text { (yeast fermentation) }\end{array}$} & \multicolumn{3}{|l|}{ Second generation } \\
\hline & & $\begin{array}{l}\text { Biochemical } \\
\text { (lignocellulosic fermentation) }\end{array}$ & $\begin{array}{l}\text { Thermochemical } \\
\text { (Fischer-Tropsch process) }\end{array}$ & $\begin{array}{l}\text { Gas fermentation } \\
\text { (hybrid process) }\end{array}$ \\
\hline \multicolumn{5}{|l|}{ Upstream process } \\
\hline Feedstock & $\begin{array}{l}\text { Specific, limited } \\
\text { Sugar crops such as wheat, corn, sugar } \\
\text { beet, and sugar cane; starch crops such } \\
\text { as potato [5]. }\end{array}$ & $\begin{array}{l}\text { Specific, unlimited } \\
\text { Lignocellulosic biomass, such as forestry } \\
\text { crops, perennial grasses and agricultural } \\
\text { residues [5]. Pre-treatment steps are usually } \\
\text { biomass type-specific to maximise efficiency } \\
\text { and minimise inhibitor production [44] }\end{array}$ & $\begin{array}{l}\text { Flexible, unlimited } \\
\text { Lignocellulosic biomass such as forestry } \\
\text { crops, perennial grasses and agricultural } \\
\text { residues [5]. Gasification process allows a } \\
\text { wide range and mixture of feedstock to be } \\
\text { used. Pre-treatment steps are biomass and } \\
\text { gasifier-specific in order to minimise } \\
\text { contaminants and produce required syngas } \\
\text { composition [44]. Can also use CO-rich } \\
\text { industrial waste gases. }\end{array}$ & $\begin{array}{l}\text { Flexible, unlimited } \\
\text { Lignocellulosic biomass such as forestry } \\
\text { crops, perennial grasses and agricultural } \\
\text { residues, or municipal solid waste (MSW) [5]. } \\
\text { Gasification process allows a wide range } \\
\text { and mixture of feedstock to be used. Can } \\
\text { also use CO-rich industrial waste gases. }\end{array}$ \\
\hline Gas composition & & - & $\begin{array}{l}\text { Specific } \\
\text { Catalyst requires specific syngas composition; } \\
\text { for example, cobalt-based FT catalyst has an } \\
\mathrm{H}_{2} \text { :CO requirement of approximately } 2.15 \text { [31]. }\end{array}$ & $\begin{array}{l}\text { Flexible } \\
\text { Microbial catalyst can utilise a range of } \\
\text { syngas } \mathrm{H}_{2}: \text { CO composition while retaining } \\
\text { product specificity [38]. }\end{array}$ \\
\hline \multicolumn{5}{|l|}{ Reactor } \\
\hline Selectivity & $\begin{array}{l}\text { High } \\
\text { Fermentation organisms produce } \\
\text { defined products in a single step [5]. }\end{array}$ & $\begin{array}{l}\text { High } \\
\text { Fermentation organisms produce defined } \\
\text { products in a single step [5]. }\end{array}$ & $\begin{array}{l}\text { Low } \\
\text { Requires large methanol recycle [53]. }\end{array}$ & $\begin{array}{l}\text { High } \\
\text { Fermentation organisms produce defined } \\
\text { products in a single step. Products as acetate, } \\
\text { butanol, or 2,3-butanediol can be produced } \\
\text { at predetermined ratios [54]. }\end{array}$ \\
\hline $\begin{array}{l}\text { Tolerance to } \\
\text { inhibitors }\end{array}$ & $\begin{array}{l}\text { Medium } \\
\text { Refined sugar streams are used. }\end{array}$ & $\begin{array}{l}\text { Low } \\
\text { Pre-treatment process releases and creates } \\
\text { inhibitors (for example, furfural) to enzymes } \\
\text { used in the saccharification process, and } \\
\text { bacteria used in the fermentation. }\end{array}$ & $\begin{array}{l}\text { Low } \\
\text { Catalysts can be irreversibly poisoned by, for } \\
\text { example, sulphur containing compounds [37]. } \\
\text { Consequently, the production of purified } \\
\text { syngas accounts for } 60 \%-70 \% \text { of the running } \\
\text { costs of a FT plant }[31] .\end{array}$ & $\begin{array}{l}\text { Medium } \\
\text { Tolerant to many impurities such as sulphur- } \\
\text { containing compounds [39]; consequently, } \\
\text { fewer gas clean-up steps are required than } \\
\text { thermochemical route. }\end{array}$ \\
\hline
\end{tabular}


Table 1. Cont.

\begin{tabular}{|c|c|c|c|c|}
\hline & \multirow{2}{*}{$\begin{array}{l}\text { First generation } \\
\text { Corn ethanol } \\
\text { (yeast fermentation) }\end{array}$} & \multicolumn{3}{|l|}{ Second generation } \\
\hline & & $\begin{array}{l}\text { Biochemical } \\
\text { (lignocellulosic fermentation) }\end{array}$ & $\begin{array}{l}\text { Thermochemical } \\
\text { (Fischer-Tropsch process) } \\
\end{array}$ & $\begin{array}{l}\text { Gas fermentation } \\
\text { (hybrid process) }\end{array}$ \\
\hline $\begin{array}{l}\text { Tolerance to } \\
\text { microbial } \\
\text { contamination }\end{array}$ & $\begin{array}{l}\text { Medium } \\
\text { Refined sugar streams are used. Despite } \\
\text { no direct plant material, there is } \\
\text { potential for contamination as } \\
\text { microorganisms growing on sugars are } \\
\text { abundant in nature [55]. Mainly batch } \\
\text { or fed-batch processes to minimise } \\
\text { contamination. }\end{array}$ & $\begin{array}{l}\text { Poor } \\
\text { Great potential for contamination as } \\
\text { microorganisms growing on sugars are } \\
\text { abundant in nature. Consequently, } \\
\text { fermentation strategies require aseptic } \\
\text { conditions at each stage. In lignocellulosic } \\
\text { fermentation contamination is an issue as } \\
\text { inhibitor compounds provide an advantage to } \\
\text { contaminating organisms. }\end{array}$ & - & $\begin{array}{l}\text { Good } \\
\text { Very few microorganisms are known to be } \\
\text { capable of living in the presence of, or } \\
\text { utilising } \mathrm{CO} . \mathrm{As} \mathrm{CO} \text { and } \mathrm{H}_{2} \text { are the only } \\
\text { carbon sources this greatly reduces } \\
\text { opportunity for microbial contamination. }\end{array}$ \\
\hline $\begin{array}{l}\text { Reactor } \\
\text { operation type }\end{array}$ & $\begin{array}{l}\text { Mainly batch or fed batch, and few } \\
\text { continuous processes [56]. }\end{array}$ & Usually batch. & $\begin{array}{l}\text { Continuous with low residence times, } \\
\text { reactions very fast. }\end{array}$ & $\begin{array}{l}\text { Batch or continuous with low residence } \\
\text { times. }\end{array}$ \\
\hline $\begin{array}{l}\text { Reactor } \\
\text { temperature }\end{array}$ & $\begin{array}{l}\text { Moderate } \\
\text { Optimum temperature of } 33{ }^{\circ} \mathrm{C}-37^{\circ} \mathrm{C} \\
\text { [57]. }\end{array}$ & $\begin{array}{l}\text { Moderate-Medium } \\
\text { Mesophilic bacteria, but also thermophilic } \\
\text { bacteria with an optimum around } 60^{\circ} \mathrm{C} \text {. }\end{array}$ & $\begin{array}{l}\text { High } \\
150{ }^{\circ} \mathrm{C}-300{ }^{\circ} \mathrm{C} .\end{array}$ & $\begin{array}{l}\text { Moderate } \\
\text { Mainly mesophilic bacteria with an optimum } \\
\text { at } 37^{\circ} \mathrm{C} \text {. Few thermophiles with an } \\
\text { optimum around } 60^{\circ} \mathrm{C} \text {. }\end{array}$ \\
\hline \multicolumn{5}{|c|}{ Downstream process } \\
\hline $\begin{array}{l}\text { Cost of product } \\
\text { recovery }\end{array}$ & $\begin{array}{l}\text { Low-Moderate } \\
\text { Sugar fermentation broths have high } \\
\text { solid levels which require separation } \\
\text { and treatment. Tolerant to high ethanol } \\
\text { levels up to } 15 \% \text {, thus require less } \\
\text { energy for distillation [58]. }\end{array}$ & $\begin{array}{l}\text { Moderate } \\
\text { Lower solids and ethanol content in } \\
\text { fermentation broth than corn ethanol route. } \\
\text { Similar separation system as biochemical } \\
\text { route can be applied with minor } \\
\text { modifications. }\end{array}$ & $\begin{array}{l}\text { Low-Moderate } \\
\text { Mixed alcohol separation. Ethanol, methanol, } \\
\text { propanol and higher level alcohols. } \\
\text { Distillation schemes used to purify } \\
\text { approximately } 90 \% \text { ethanol to greater than } \\
99.5 \% \text { purity. Separation of mixed } \\
\text { components increases costs. }\end{array}$ & $\begin{array}{l}\text { Moderate } \\
\text { Lower solids and ethanol content in } \\
\text { fermentation broth than biochemical route. } \\
\text { Similar separation system scheme as } \\
\text { biochemical route can be applied with } \\
\text { minor modifications. }\end{array}$ \\
\hline
\end{tabular}




\section{Biomass Syngas and Gasification}

Gasification is a process where feedstock is thermochemically converted to carbon monoxide and hydrogen-rich synthesis gas through the use of an agent such as oxygen, steam, air, or supercritical water $[52,59,60]$. This process is efficient, with an overall rate of energy conversion of approximately $75 \%-80 \%$ [52]. Gasification has been in use for centuries, although it was the 1970s oil crisis which renewed interest in the process for heat and power applications, and for use with Fischer-Tropsch catalysis to produce liquid fuels [59]. Today, most mature gasification technology in commercial use is coal and petroleum-based technology; however, the use of biomass as a feedstock is undergoing intensive research and development, as reflected by increased publication and patent activity over the past ten years [59].

Biomass gasification has been able to build on previously developed gasification technology [61], although differences in feedstock and required synthesis gas composition for downstream usage has necessitated novel developments.

Syngas consists primarily of carbon monoxide $(\mathrm{CO})$, hydrogen $\left(\mathrm{H}_{2}\right)$ and carbon dioxide $\left(\mathrm{CO}_{2}\right)$. Syngas produced from biomass will also contain other gases, solids and condensable volatiles [62]. Besides $\mathrm{CO}, \mathrm{CO}_{2}$ and $\mathrm{H}_{2}$, other species in descending order of highest reported concentrations include: water $\left(\mathrm{H}_{2} \mathrm{O}\right)$; methane $\left(\mathrm{CH}_{4}\right)$; ethene $\left(\mathrm{C}_{2} \mathrm{H}_{4}\right)$; ethane $\left(\mathrm{C}_{2} \mathrm{H}_{6}\right)$; ethyne $\left(\mathrm{C}_{2} \mathrm{H}_{2}\right)$; benzene $\left(\mathrm{C}_{6} \mathrm{H}_{6}\right)$; naphthalene $\left(\mathrm{C}_{10} \mathrm{H}_{8}\right)$; ammonia $\left(\mathrm{NH}_{3}\right)$ and hydrogen cyanide $(\mathrm{HCN})$; nitrogen oxides $\left(\mathrm{NO}_{\mathrm{X}}\right)$; sulphur dioxide $\left(\mathrm{SO}_{2}\right)$; and hydrogen sulphide $\left(\mathrm{H}_{2} \mathrm{~S}\right)$ and carbonyl sulphide (COS) [62]. Concentrations of these species depend on the feedstock constitution and gasification technique used [62].

There are three stages in the conversion of biomass to synthesis gas: feedstock pre-treatment and feeding, gasification, and gas cleaning [52]. Pre-treatment modifies the physical or chemical properties of the biomass feedstock in order to homogenise it for efficient gasification, and to render it suitable for storage and handling. These processes include drying, pulverisation, and pelletisation [63], and the techniques applied depend on the nature of the feedstock and the gasification method used. The pre-treatment step is modulated in order to optimise for different applications. Although pre-treatment is typically designed to only modify the physical properties of biomass, it has been shown that chemical features of biomass feedstock may also influence the efficiency of the gasification process $[64,65]$. For example, composting has been shown to increase the lignin concentration and thus improve hydrogen production during pyrolysis [66,67]. Pre-treatment steps which favourably modify the chemical profile of lignocellulosic feedstock are an area for further research.

Optimal drying of biomass is important because increasing moisture content reduces the energy content of the material [52], and unless the feedstock is being transported as slurry through pipes, increases transportation costs. Additionally, a high moisture content can result in incomplete cracking of hydrocarbons released in the pyrolysis zone by reducing the peak temperature in the oxidation zone [52]. Furthermore, moisture can increase the $\mathrm{H}_{2}$ and $\mathrm{CH}_{4}$ content of the gas while reducing the $\mathrm{CO}$ content through the water gas shift reaction, giving a net decrease in product gas calorific value compared to that from dried biomass [52]. Generally, feedstocks with a moisture content over $30 \%$ must be dried to below 10\%-15\% before gasification can occur [52]. Driers used to achieve this include directly heated rotary driers which utilise energy from the flue gas, or indirectly heated 
fluidised bed driers which use steam. Commercial biomass gasifiers are reported as running on feedstock with $20 \%-50 \%$ wt moisture [68].

Pulverisation improves the gasification efficiency and product profile, and typical feed particle sizes range from 20-80 $\mathrm{mm}$ [52]. It has been shown that fluidised bed gasification performance increases with a size reduction of biomass particles [69-71], although at the expense of increased capital and operating costs associated with the size reduction. These properties affect a range of variables such as heat conduction and mass transfer, all affecting gasification kinetics, carbon conversion, and tar concentration [63]. Additionally, there are practical considerations when investigating particle size, as they can affect the flow of feedstock into the gasifier [52]. This pre-treatment step has undergone significant optimisation recently [63], and there is scope for more work with regard to exploring the optimum particle sizes and the effect of pelletising biomass feedstock.

The mechanism of the gasification process is distinct from combustion as it is a two stage process, with the following key reactions occurring [52]:

$$
\begin{array}{lll}
\text { Partial oxidation: } & \mathrm{C}+0.5 \mathrm{O}_{2} \leftrightarrow \mathrm{CO} & \Delta \mathrm{H}_{\mathrm{vap}}=-268 \mathrm{MJ} / \mathrm{kg} \mathrm{mol}, \Delta \mathrm{G}^{\circ \prime}=-151 \mathrm{~kJ} / \mathrm{mol} \\
\text { Complete oxidation: } & \mathrm{C}+\mathrm{O}_{2} \leftrightarrow \mathrm{CO}_{2} & \Delta \mathrm{H}_{\mathrm{vap}}=-406 \mathrm{MJ} / \mathrm{kg} \mathrm{mol}, \Delta \mathrm{G}^{\circ \prime}=-423 \mathrm{~kJ} / \mathrm{mol} \\
\text { Water gas reaction: } & \mathrm{C}+\mathrm{H}_{2} \mathrm{O} \leftrightarrow \mathrm{CO}+\mathrm{H}_{2} & \Delta \mathrm{H}_{\mathrm{vap}}=+118 \mathrm{MJ} / \mathrm{kg} \mathrm{mol}, \Delta \mathrm{G}^{\circ \prime}=-100 \mathrm{~kJ} / \mathrm{mol}
\end{array}
$$

Carbon monoxide and hydrogen can undergo the following further reactions [52]. The direction of these reactions depends on a range of variables including temperature, pressure and concentration of the reactants, as well as the gasifying agent and method of operation.

$$
\begin{aligned}
& \text { Water gas-shift reaction: } \mathrm{CO}+\mathrm{H}_{2} \mathrm{O} \leftrightarrow \mathrm{CO}_{2}+\mathrm{H}_{2} \quad \Delta \mathrm{H}_{\mathrm{vap}}=-42 \mathrm{MJ} / \mathrm{kg} \mathrm{mol}, \Delta \mathrm{G}^{\circ \prime}=-20 \mathrm{~kJ} / \mathrm{mol} \\
& \text { Methane formation: } \quad \mathrm{CO}+3 \mathrm{H}_{2} \leftrightarrow \mathrm{CH}_{4}+\mathrm{H}_{2} \mathrm{O} \quad \Delta \mathrm{H}_{\mathrm{vap}}=-88 \mathrm{MJ} / \mathrm{kg} \mathrm{mol}, \Delta \mathrm{G}^{\circ \prime}=-151 \mathrm{~kJ} / \mathrm{mol}
\end{aligned}
$$

The reactions that occur during the gasification process are fairly complex, and can be summarised into four key stages: drying, pyrolysis, oxidation, and reduction [72]. Drying occurs at $100{ }^{\circ} \mathrm{C}-200{ }^{\circ} \mathrm{C}$, and following this, pyrolysis occurs where the biomass is thermally decomposed in the absence of oxygen, releasing hydrocarbon gases and reducing the biomass to carbonised biomass. Volatile components of the biomass are reduced, and result in the release of compounds including methane, carbon monoxide, and carbon dioxide gases as well as water and tars [72,73].

Oxidation occurs as the char (carbonaceous solid) reacts with oxygen in the air to form carbon dioxide, and hydrogen in the biomass is also oxidised to generate water; considerable heat is released during this step [72]. Here, carbon monoxide can be predominantly generated (relative to carbon dioxide) provided oxygen is present in sub-stoichiometric quantities, as carbon is partially oxidised. Char gasification is the rate-limiting step in the process, and rates depend on variables such as the pressure and heating rate [74], as well as the relative concentrations of gasifying species and the properties of the biomass. Finally, mostly endothermic reduction reactions occur at $800{ }^{\circ} \mathrm{C}-1000{ }^{\circ} \mathrm{C}$, in the absence of oxygen [72].

Although coal gasification typically employs entrained flow designs, biomass gasification has been demonstrated using a range of technologies of which fixed bed, fluidised bed and entrained flow are the most common [59]. 
Fixed bed gasification is the traditional design and today is generally used at low operational scales $[59,75]$. In this relatively simple process operated at around $1000{ }^{\circ} \mathrm{C}$, a fixed bed of feedstock is exposed to the gasification agent, usually through an updraft or downdraft direction of airflow [52]. In updraft gasifiers, zones are temperature controlled through air humidification. Feedstock is introduced through the top, and gasification agents through the bottom of the unit. At the top of the gasifier the pre-treated biomass feedstock is dried, with the gases cooled by this stage to about $200{ }^{\circ} \mathrm{C}-300{ }^{\circ} \mathrm{C}$. The biomass is pyrolysed below this with the release of volatile compounds, and solid char falls to the air inlet and is combusted, with the temperature reaching $1,000{ }^{\circ} \mathrm{C}$. Ash is taken out of the bottom of the gasifier and the hot gases are reduced as they pass upwards [52]. Synthesis gas produced by updraft gasifiers has a low temperature and thus the process has high energy efficiency [75]. Although this design produces gas with low particulate content, tar content is often high.

Downdraft technology is similar to updraft except both the feedstock and gasification agent are introduced through the top of the unit [52]. This has the advantage of producing synthesis gas with very low tar content, as the gas leaves the gasifier through the hot zone, partially cracking the tars formed during gasification. However, as the gas leaves the gasifier at temperatures around $700{ }^{\circ} \mathrm{C}$ the process has a lower energy efficiency, and the particulate content of the gas is high [75]. Another configuration undergoing development is the two stage fixed bed reactor [75], where pyrolysis occurs in the first reactor and then gases react with the char in the second reactor to produce the final product, resulting in gas with low tar content [76].

Fluidised bed gasification has generally been used for biomass gasification at larger scales of operation than fixed bed [59], and is reviewed by Siedlecki et al. [68]. A small fraction of feedstock is added to a bed of fine-grained material, most commonly silica sand, which is fluidised by a stream of introduced gasification medium. This allows the mixing of the hot bed material, combustion gas and feedstock, with a homogeneous temperature achieved throughout the gasification zone. In circulating fluidised bed gasification the fine-grained bed material circulates between the gasification chamber and a cyclone separator. Ash is removed in the separator, leaving behind the bed material and char, allowing high throughput operation. In bubbling bed technology air is introduced through a grate at the bottom of the vessel, with the bed material into which the feedstock is introduced directly above. The temperature of this bed is kept at $700{ }^{\circ} \mathrm{C}-900{ }^{\circ} \mathrm{C}$ through the control of the air/biomass ratio [52]. Pyrolysis occurs in the hot bed and tars produced are cracked by contact with this material, resulting in a product gas with low tar content [52]. In a comparison based on tar, carbon conversion and scale-up potential, circulating fluidised bed technology was observed to be superior to bubbling bed technology [68].

Entrained flow gasification has seen limited use in biomass gas fermentation. Generally applied at large scales of operation, it is the preferred technology for coal gasification, especially when synthesis gas is used for the Fischer-Tropsch process [59]. Here, very small particles of feedstock are entrained in the gasification medium, usually oxygen or steam [59]. This process produces gas very low in tar, has favourable exit gas temperatures and conversion efficiencies, and is particularly feedstock flexible. However, it requires significant feedstock pre-treatment, with feedstock requiring intensive pulverisation to less than $0.4 \mathrm{~mm}$ in diameter, which is difficult to achieve with lignocellulosic biomass [52]. Although this process was initially thought to be unsuitable for most biomass gasification [52], recent work has been carried out where biomass is pre-treated through torrefaction to enable its use as a feedstock [77]. 
Downdraft fixed bed gasifiers and fluidised bed gasifiers are the most popular technologies for biomass gasification [59,72]. Of these, fluidised bed gasification is the preferred technology to be used in conjunction with thermochemical or gas fermentation methods [59,68]. Gas composition and gasification efficiency are the two key factors used to measure the performance of a gasification technique, and variants of fluidised bed gasifiers have been shown to produce gas with low tar content at a relatively high efficiency [68].

In a recent 30-year global overview of biomass gasification, Kirkels and Verbong concluded that biomass gasification is not yet a mature technology, no dominant design has arisen, and development of the technology is likely to continue in a gradual manner [59]. Problems to be overcome in the commercialisation of gasification technology for biomass syngas fermentation are discussed in Section 8. As well as the described gasification technologies, which are well-developed due to their use in coal gasification, a few novel technologies have been developed over the last decade, including plasma gasification and supercritical water gasification [60]. Plasma gasification is of interest due to low tar content in the producer gas and high conversion efficiencies [78]. Likewise, the use of water in the supercritical state as a gasification agent has demonstrated improved gasification efficiency, and has recently undergone considerable research for the production of hydrogen [79]. Because supercritical water gasification allows the gasification of wet biomass, it has been investigated with a wide range of feedstocks [80], although it has yet to be demonstrated at scale.

\section{Biochemistry of Gas Fermentation: the Reductive Acetyl-CoA, Wood-Ljungdahl, ACS/CODH Pathway}

Acetogens are a group of bacteria capable of fermenting $\mathrm{CO}$ and/or $\mathrm{CO}_{2}$ and $\mathrm{H}_{2}$ into acetyl-CoA (and from there into acetic acid, ethanol and other metabolic end-products, as discussed in the next section) via the reductive acetyl-CoA pathway [81]. The reductive acetyl-CoA pathway, also known as the Wood-Ljungdahl pathway, was first characterised by Wood and Ljungdahl in 1966 when they proposed a scheme for the synthesis of acetate from $\mathrm{CO}_{2}$ by the organism Clostridium thermoaceticum, now classified as Moorella thermoacetica [82,83]. Variations of this pathway are also found in methanogenic and sulphate-reducing organisms [81]; however, only acetogens are known to synthesise metabolic end-products that can be used as liquid transportation fuels. The biochemistry of this pathway has been comprehensively described in numerous reviews, including those by Wood and Ljungdahl themselves [83,84], Ragsdale and co-workers [85,86], and Drake and co-workers [87]. It is hypothesised that the reductive acetyl-CoA pathway was one of the first biochemical pathways, used by the first autotrophs $c a$. 3.8 billion years ago [85,88]. These organisms used $\mathrm{CO}$ and $\mathrm{H}_{2}$ as energy sources and $\mathrm{CO}_{2}$ as an electron acceptor approximately one billion years before significant quantities of $\mathrm{O}_{2}$ appeared in the Earth's atmosphere [89].

The reductive acetyl-CoA pathway is illustrated in Figure 1 and is made up of carbonyl (sometimes referred to as "Eastern" [90]) and methyl (or "Western") branches. Ragsdale provides an excellent history of the elucidation of the different branches and a background to the biochemistry and enzymology of the pathway [90]. 
Figure 1. Wood-Ljungdahl pathway of acetogens and their metabolic end products [54,85,91-93]. Organisms are grouped according to their main interest for gas fermentation, but are able to produce more than one product, as outlined in Section 5 (for example C. carboxidivorans is able to produce acetate and ethanol in addition to butyrate and butanol). Single reactions shown do not represent stoichiometric balances.

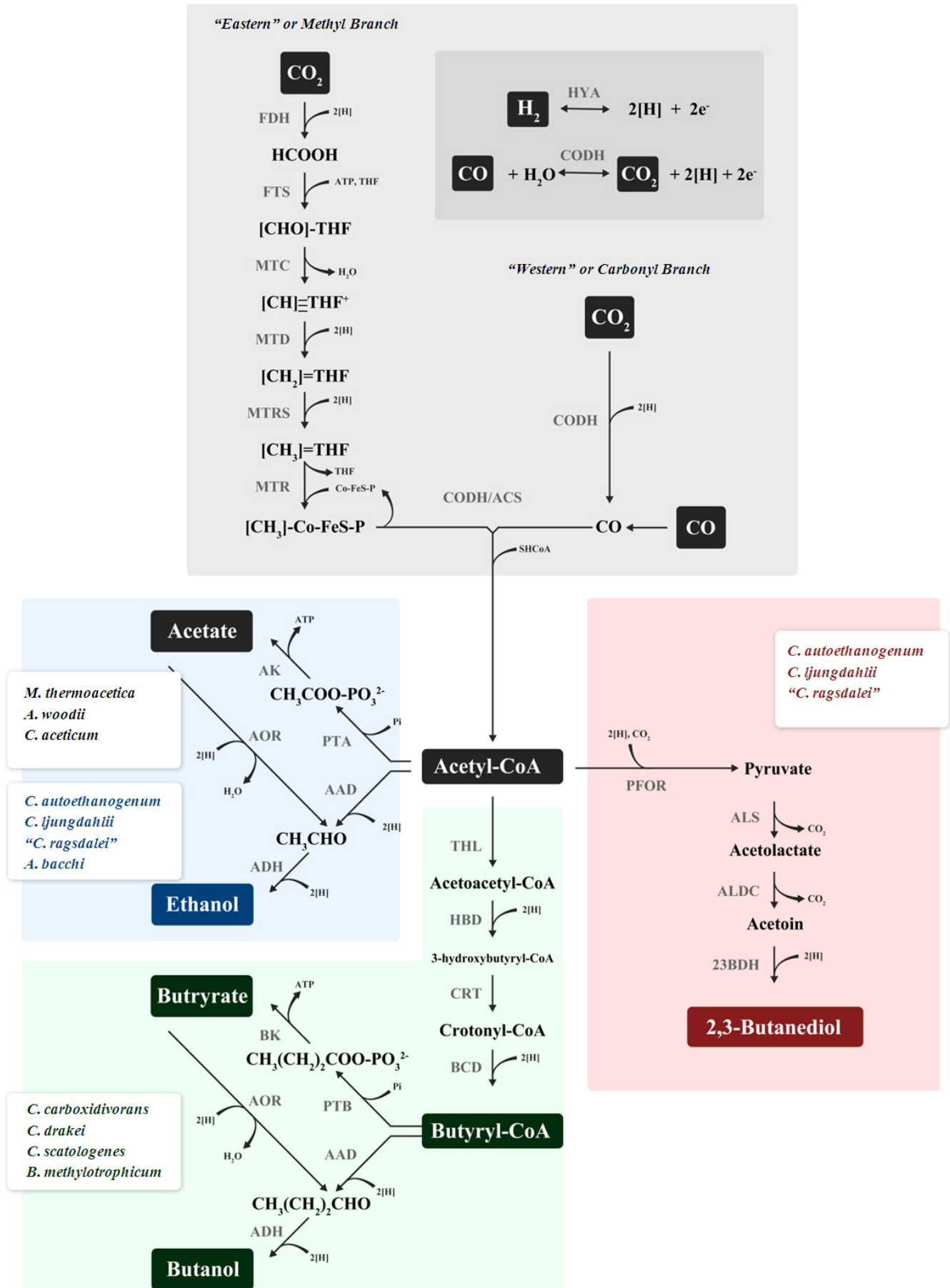

Abbreviations: AAD, alcohol/aldehyde dehydrogenase; ACS, acetyl-CoA synthase; ADH, alcohol dehydrogenase; AK, acetate kinase; ALDC, acetolactate decarboxylase; ALS, acetolactate synthase; AOR, aldehyde:ferredoxin oxidoreductase; BCD, butyryl-CoA dehydrogenase; BK, butyrate kinase; CODH, CO dehydrogenase; Co-Fes-P, corrinoid iron-sulphur protein; CRT, crotonase; FDH, formate dehydrogenase; FTS, formyl-THF synthetase; HBD, 3-hydroxybutyryl-CoA dehydrogenase; HYA, hydrogenase; MTC, methenyl-THF cylcohydrolase; MTD, methylene-THF dehydrogenase; MTR, methyltransferase; MTRS, methylene-THF reductase; PFOR, pyruvate:ferredoxin oxidoreductase; PTA, phosphotransacetylase; PTB, phosphotransbutyrylase; THF, tetrahydrofolate; THL, thiolase. 
$\mathrm{CO}$ enters the pathway through two routes. One molecule can directly enter the Western branch as $\mathrm{CO}$, while another molecule of $\mathrm{CO}$ can be oxidised to $\mathrm{CO}_{2}$ by a monofunctional carbon monoxide dehydrogenase $(\mathrm{CODH})$ in the biological water gas shift reaction, with the resulting energy of this reaction being captured as reduced ferredoxin [94,95].

Some of the resulting $\mathrm{CO}_{2}$ then enters the Eastern branch of the reductive acetyl-CoA pathway. This depends if CO serves as both carbon and energy source, or if an additional energy source such hydrogen is present which can be utilised in a hydrogenase reaction (as illustrated in Figure 1). It should be noted though that electron production is thermodynamically more favourable from CO than from $\mathrm{H}_{2}$ [96], and hydrogenases are reversibly inhibited by $\mathrm{CO}$ [97-99].

Thus, at high CO concentrations, no or only little hydrogen uptake will occur, but it will increase once $\mathrm{CO}$ is utilised and the concentration drops. Ethanol and acetate can be produced according to the following reactions: with $\mathrm{CO}$ as the sole carbon an energy source, as in Equations (6,7); with $\mathrm{CO}$ as a carbon source and both $\mathrm{CO}$ and $\mathrm{H}_{2}$ as the energy source, according to Equations (8-10); and with $\mathrm{CO}_{2}$ as carbon source and $\mathrm{H}_{2}$ as energy source, as in Equations $(11,12)$ [84]:

$$
\begin{gathered}
6 \mathrm{CO}+3 \mathrm{H}_{2} \mathrm{O} \rightarrow \mathrm{CH}_{3} \mathrm{CH}_{2} \mathrm{OH}+4 \mathrm{CO}_{2}\left(\Delta \mathrm{G}^{\circ \prime}=-224 \mathrm{~kJ} / \mathrm{mol}\right) \\
4 \mathrm{CO}+2 \mathrm{H}_{2} \mathrm{O} \rightarrow \mathrm{CH}_{3} \mathrm{COOH}+2 \mathrm{CO}_{2}\left(\Delta \mathrm{G}^{\circ \prime}=-175 \mathrm{~kJ} / \mathrm{mol}\right) \\
3 \mathrm{CO}+3 \mathrm{H}_{2} \rightarrow \mathrm{CH}_{3} \mathrm{CH}_{2} \mathrm{OH}+\mathrm{CO}_{2}\left(\Delta \mathrm{G}^{\circ \prime}=-164 \mathrm{~kJ} / \mathrm{mol}\right) \\
2 \mathrm{CO}+2 \mathrm{H}_{2} \rightarrow \mathrm{CH}_{3} \mathrm{COOH}\left(\Delta \mathrm{G}^{\circ \prime}=-135 \mathrm{~kJ} / \mathrm{mol}\right) \\
2 \mathrm{CO}+4 \mathrm{H}_{2} \rightarrow \mathrm{CH}_{3} \mathrm{CH}_{2} \mathrm{OH}+\mathrm{H}_{2} \mathrm{O}\left(\Delta \mathrm{G}^{\circ \prime}=-144 \mathrm{~kJ} / \mathrm{mol}\right) \\
2 \mathrm{CO}_{2}+6 \mathrm{H}_{2} \rightarrow \mathrm{CH}_{3} \mathrm{CH}_{2} \mathrm{OH}+3 \mathrm{H}_{2} \mathrm{O}\left(\Delta \mathrm{G}^{\circ \prime}=-104 \mathrm{~kJ} / \mathrm{mol}\right) \\
2 \mathrm{CO}_{2}+4 \mathrm{H}_{2} \rightarrow \mathrm{CH}_{3} \mathrm{COOH}+2 \mathrm{H}_{2} \mathrm{O}\left(\Delta \mathrm{G}^{\circ}=-95 \mathrm{~kJ} / \mathrm{mol}\right)
\end{gathered}
$$

In the Eastern (or methyl) branch, formate dehydrogenase (FDH) reduces $\mathrm{CO}_{2}$ to formate, which is then attached to tetrahydrofolate (THF) by 10-formyl-THF synthetase [85]. This undergoes several reductive steps catalysed by enzymes including methylene-THF cyclohydrolase (MTC), methylene-THF dehydrogenase (MTD) and methylene-THF reductase (MTRS). Methyltransferase (MTR) then transfers the methyl group from methyl-THF to a corrinoid-FeS protein [100], and then this methyl group is provided as the methyl group of Acetyl-CoA. Used by all organisms in one-carbon metabolism, the genes encoding the enzymes that operate in the Eastern branch are ubiquitous, and in M. thermoacetica are dispersed throughout the genome [85], while found in a large single cluster in C. ljungdahlii [91], C. autoethanogenum [54], C. ragsdalei [54], C. carboxidivorans [101] and A. woodii [102] with the exception of the genes for formate dehydrogenase.

The Western (or carbonyl) branch is unique to anaerobic microorganisms [90]. CO can either be used directly, or generated from $\mathrm{CO}_{2}$, and serves as the carbonyl group for acetyl-CoA synthesis. The unique multi-subunit bifunctional metaloenzyme $\mathrm{CO}$ dehydrogenase (CODH)/Acetyl-CoA synthase (ACS) is a characteristic and name-giving feature of the pathway [103]. This key enzyme is capable of reducing $\mathrm{CO}_{2}$ to $\mathrm{CO}$ in the Western branch, and accepting the methyl group of the corrinoid-Fe/S-protein of the Eastern branch and condensing both the methyl and the carbonyl moiety with a CoA group to produce a molecule of coenzyme-A. Details of this important mechanism have been well-reviewed [104-106]. The genes for this complex are co-localised with the other 
Wood-Ljungdahl pathway genes in the case of C. ljungdahlii [91], C. autoethanogenum [54] and C. ragsdalei [54], while being localized in a separate acs cluster in $M$. thermoacetica [85], C. carboxidivorans [101] and A. woodii [102].

Acetyl-CoA is then converted into acetate via phosphotransacetylase and acetate kinase reactions [85]. The genes for these enzymes are organised in a single operon in all sequenced acetogens to date $[54,85,91,101,102]$. In the acetate kinase reaction, one molecule of ATP is gained by substrate level phosphorylation (SLP) which is used to compensate for the ATP required to activate formate in the Eastern branch of the Wood-Ljungdahl pathway (Figure 1). While there is still no net ATP gain on autotrophic growth by SLP, even when acetate is produced, additional energy must come via electron transport phosphorylation (ETP), chemiosmosis and the generation of ion gradients across the cytoplasmic membrane. As none of the enzymes of the Wood-Ljungdahl pathway were found to be membrane bound and capable of generating such a membrane potential, a coupling site and electron carriers have been proposed $[85,91,102,107]$. In the case of $M$. thermoacetica, menaquinone and cytochromes have been detected in the membrane and thought to act as a coupling site $[85,107,108]$. Cytochromes have also been detected in C. formicoaceticum [109]. In A. woodii [102] and C. ljungdahlii [91] there is no evidence of a membrane-bound electron transport system with cytochromes and menaquinones, but the group of Volker Müller identified an Rnf complex as a potential coupling site [110]. This ferredoxin: NAD+-oxidoreductase was first discovered in Rhodobacter capsulatus where it is involved in nitrogen fixation, and is widespread, although not present in $M$. thermoacetica [111]. CO oxidation and hydrogenase reactions could be coupled directly with ferredoxin to the Rnf complex, while other reactions such as caffeate reduction may be coupled via electron transferring flavoproteins [110,112,113]. In the Wood-Ljungdahl pathway, the highly exergonic reduction step $\left(\Delta \mathrm{G}^{\mathrm{o}^{\prime}}=-22 \mathrm{~kJ} \mathrm{~mol}^{-1}\right)$ of methylene-THF to 5-methyl-THF (Figure 1) is hypothesised to be coupled accordingly [91,102,107,114]. Recently, the novel mechanism of electron bifurcation was demonstrated for several enzymes [115-118], which allows the coupling of an endogenic with an exergonic reaction and which may also play an important role in acetogenesis, as shown for the hydrogenase enzyme of $A$. woodii [119]. While the Rnf complex and $\mathrm{F}_{1} \mathrm{~F}_{\mathrm{O}}$ ATPase of A. woodii are strictly sodium dependent [102,120], C. ljungdahlii [91] and M. thermoacetica [121] can use a proton gradient. For the methanogenic archaeon Methanosarcina acetivorans, a promiscuous ATPase has recently been identified that can utilize both $\mathrm{Na}^{+}$and $\mathrm{H}^{+}$[122]. In addition to acetate, some gas fermentation microorganisms are able to produce products like ethanol; these organisms and products are detailed in the following section.

\section{Organisms and Products}

Acetogens are anaerobic bacteria which are ubiquitous in nature and very important from an ecological standpoint due to the key role they play in the global carbon cycle [87]. Acetogens have been isolated from a variety of habitats including soil, sediments, and the intestinal tracts of animals and humans, and are found worldwide. For example, acetogens can be found in the digestive system of termites where they are thought to exist in a symbiotic relationship, producing acetate, which is thought to be the primary energy source for the termite [123,124]. All acetogens described to date produce acetate [87]. Although over 100 acetogenic bacteria from 22 genera have been isolated [81], 
the best characterised and researched of these fit into the genera Acetobacterium and Clostridium. Drake provides a good definition of an acetogen [87,125]:

"An anaerobe that can use the acetyl-CoA pathway as a 1) mechanism for the reductive synthesis of acetyl-CoA from $\mathrm{CO}_{2}, 2$ ) terminal electron-accepting, energy-conserving process, and 3) mechanism for the fixation (assimilation) of $\mathrm{CO}_{2}$ in the synthesis of cell carbon."

Acetogenic organisms which have been investigated for use in commercial syngas fermentation are highlighted according to their product spectrum in Figure 1. These products include acetate, ethanol, butyrate, butanol and 2,3-butanediol. Ethanol and butanol are used as liquid transportation fuels, while acetate and 2,3-butanediol are of interest in the chemical industry.

All acetogens produce acetate, and well characterised examples include Moorella thermoacetica, Acetobacterium woodii, and Clostridium aceticum. Those primarily used and characterised for the production of ethanol include Clostridium ljungdahlii, Clostridium autoethanogenum, "Clostridium ragsdalei" and Alkalibaculum bacchi. Butanol production has been observed with Clostridium carboxidivorans and Butyribacterium methylotrophicum, while Clostridium drakei and Clostridium scatologenes are known to produce butyrate. In addition, the production of 2,3-butanediol has recently been reported for Clostridium ljungdahlii, Clostridium autoethanogenum and "Clostridium ragsdalei" [126].

\subsection{Acetate Producers}

As discussed in the previous section, acetyl-CoA serves as a key intermediate in this class of bacteria for both anabolism and catabolism. It is converted into acetate via phosphotransacetlyase and acetate kinase reactions, with one molecule of ATP gained by substrate level phosphorylation (SLP). All acetogens isolated to date produce acetate, with the majority being homoacetate producers (homoacetogens) [87].

Acetic acid is an important industrial feedstock which has been traditionally produced from petrochemical feedstocks through methanol carbonylation or acetaldehyde oxidation [127]. Used as a starting material for vinyl acetate and acetic anhydride synthesis [127], demand for acetic acid has grown over the past decade and is expected to reach 12.15 million tons by 2017 [128]. Three organisms have been used for acetate or calcium-magnesium-acetate (CMA) production: C. aceticum, $M$. thermoacetica and $A$. woodii $[125,126,129,130]$.

While acetic acid has no potential as fuel, some organisms such as oleaginous yeasts are able to convert acetic acid and other volatile fatty acids (VFAs) into lipids, which could be used as biodiesel $[131,132]$. A process scheme has been proposed combining such a fermentation process with a $\mathrm{CO}_{2}$ fermentation process [133]. An acetogen converts $\mathrm{CO}_{2}$ to acetate, which is then used by oleaginous yeast to produce lipids with $\mathrm{CO}_{2}$ as a by-product which could then be fed back to the acetogen. The reducing power can either come from $\mathrm{H}_{2}$ or electricity.

C. aceticum was the first acetogen to be isolated, from a soil sample in 1936 [134,135], although the strain was subsequently lost [136]. In 1980, spores of the original strain were serendipitously found and reactivated [136], while at the same time it was separately re-isolated [137]. Producing acetate from growth-supporting substrates including $\mathrm{H}_{2}$ and $\mathrm{CO}_{2}, \mathrm{CO}$ and a range of sugars (fructose, ribose, 
glutamate, fumarate, malate and pyruvate), $C$. aceticum has an optimal growth temperature of $30{ }^{\circ} \mathrm{C}$ [136]. A genome sequence for the organism is currently under construction [46], and C. aceticum has recently been investigated for the production of acetic acid from synthesis gas [126], with a published productivity of $1.28 \mathrm{~g} \mathrm{~L}^{-1}$ with $100 \% \mathrm{CO}$ conversion [138].

M. thermoacetica is considered a model acetogen [139] and it was used by Wood and Ljungdahl and later by Ragsdale and others to elucidate the Wood-Ljungdahl pathway [85]. M. thermoacetica is a thermophilic bacterium isolated from horse manure and was originally characterised in 1942 as Clostridium thermoaceticum [140]. It forms acetate from a diverse range of substrates, with an optimal growth temperature of $55^{\circ} \mathrm{C}-60{ }^{\circ} \mathrm{C}$. Over the past ten years new Moorella strains have been isolated and explored for both acetate and ethanol production, although only very low ethanol productivities have been reported [141-143]. Due to its role in the elucidation of the Wood-Ljungdahl pathway, M. thermoacetica is well characterised [139], and in 2008 became the first acetogen to have a genome sequence published [144], helping to improve understanding of the acetogenic metabolism and mode of energy conservation. Using a dilution-cycle fermentation mode, up to $108 \mathrm{~g} \mathrm{~L}^{-1}$ acetate has been produced from sugar using $M$. thermoacetica [145]. Production rates of up to $14.3 \mathrm{~g} \mathrm{~L}^{-1} \mathrm{~h}^{-1}$ acetate from sugar have been reported in continuous culture, but only at low concentrations of $7.1 \mathrm{~g} \mathrm{~L}^{-1}$ [146].

A. woodii was isolated from estuary sediment in 1977 [147], and is capable of forming acetate from $\mathrm{H}_{2}$ and $\mathrm{CO}_{2}$, and $\mathrm{CO}$. With fructose, small amounts of ethanol have been reported under certain conditions [148]. A. woodii has a reported optimal growth temperature of $30^{\circ} \mathrm{C}$, and other substrates include glucose, lactate, glycerate, and formate [147]. Recently, the genome of $A$. woodii was sequenced [102]. As outlined earlier, most recently published research on $A$. woodii has focused on elucidating the acetogenic mode of energy conservation [110,112,120,149] and its sodium-dependant metabolism [102,120]. However, studies have demonstrated its use as a biocatalyst for the production of acetate, reporting an acetate concentration of $44 \mathrm{~g} \mathrm{~L}^{-1}$ after 11 days, with a maximum cell specific acetate productivity of $6.9 \mathrm{~g}_{\text {acetate }} \mathrm{g}_{\mathrm{cdw}}{ }^{-1} \mathrm{~d}^{-1}$ achieved with $\mathrm{H}_{2}$ and $\mathrm{CO}_{2}$ as substrate [130].

\subsection{Ethanol Production}

Ethanol can be produced either directly from acetyl-CoA in a two-step reaction via acetaldehyde, or via acetate and subsequent reduction to acetaldehyde. The latter proceeds via a ferredoxin: aldehyde oxidoreductase, coupled to, for example, $\mathrm{CO}$ oxidation, while the direct route utilises an aldehyde dehydrogenase or a bifunctional aldehyde/alcohol dehydrogenase enzyme [150]. Acetaldehyde is finally reduced to ethanol via an alcohol dehydrogenase. In some acetogens, micro-compartments have been found in which this reaction may take place [91]. In the next two sections, strategies to optimise for ethanol production, either by fermentation or mutagenesis and genetic modification, are discussed.

Ethanol can be used as a complete transportation fuel, and it is also used to supplement gasoline as a fuel blend, improving octane and reducing emissions. Commercial applications of gas fermentation to date have primarily focused on the production of ethanol [150], using the following organisms as biocatalysts.

C. ljungdahlii was isolated from chicken waste in 1988 by Barik et al. [151] and later described by Tanner et al. in 1993 [152]. With autotrophic growth on $\mathrm{CO}$, and on $\mathrm{H}_{2}$ and $\mathrm{CO}_{2}$, this organism has become one of the most well studied acetogens following the elucidation of its genome [91]. 
C. ljungdahlii also grows heterotrophically on a range of substrates including fructose, glucose, ethanol and pyruvate [152]. When synthesis gas is used as a substrate, both acetate and ethanol are produced, with an ideal growth temperature of $37{ }^{\circ} \mathrm{C}$ [152]. Early work with a cell recycled culture with a $560 \mathrm{~h}$ fermentation time achieved an ethanol concentration of $48 \mathrm{~g} \mathrm{~L}^{-1}$ [153].

"C. ragsdalei" or strain "P11" was isolated from duck pond sediment by researchers from The University of Oklahoma and Oklahoma State University and is described in a patent [154]. "C. ragsdalei" has been explored for the production of ethanol from syngas [155-157], with growth temperatures of $32{ }^{\circ} \mathrm{C}-37{ }^{\circ} \mathrm{C}$ [157] and a batch fermentation reported ethanol concentration of $1.99 \mathrm{~g} \mathrm{~L}^{-1}$ [158]. In a $100 \mathrm{~L}$ stirred tank reactor (STR) an ethanol concentration of $25.26 \mathrm{~g} \mathrm{~L}^{-1}$ was achieved over a fermentation duration of 59 days [159].

C. autoethanogenum was isolated from rabbit faeces in 1994 and has a reported ideal growth temperature of $37^{\circ} \mathrm{C}$ [160]. Minimal research was done on C. autoethanogenum as a gas fermenting organism until the past five years when it has undergone research for the production of ethanol with synthesis gas or pure carbon monoxide as feedstock [161-164]. Only low-level ethanol production of $0.32 \mathrm{~g} \mathrm{~L}^{-1}$ [164], $0.28 \mathrm{~g} \mathrm{~L}^{-1}$ [160] and $0.26 \mathrm{~g} \mathrm{~L}^{-1}$ [163] has been reported for this strain, with $\mathrm{CO}$ as the sole carbon source.

A. bacchi was isolated from livestock-impacted soil in 2010 and has been recently investigated for the production of ethanol from syngas, with a reported ideal growth temperature of $37^{\circ} \mathrm{C}$ [165]. This was notably carried out at an initial $\mathrm{pH}$ between 7.7 and 8.0, with A. bacchi moderately alkaliphilic [166]. A. bacchi strain CP15 achieved a maximum reported productivity of $1.7 \mathrm{~g} \mathrm{~L}^{-1}$ with $76 \%$ ethanol yield from utilised $\mathrm{CO}$ with pure coal derived syngas ( $\left.40 \% \mathrm{CO}, 30 \% \mathrm{CO}_{2}, 30 \% \mathrm{H}_{2}\right)$. Using biomass syngas ( $20 \% \mathrm{CO}, 15 \% \mathrm{CO}_{2}, 5 \% \mathrm{H}_{2}, 60 \% \mathrm{~N}_{2}$ ), ethanol yield from utilised $\mathrm{CO}$ has been reported at $65 \%$ [166].

\subsection{Butanol}

Butanol (butan-1-ol) has been primarily considered for use as a bulk chemical for the production of butyl acetate and butyl acrylate, but it has also recently been proposed for use as an advanced biofuel or in a blend with gasoline to enhance the octane rating. Butanol has a higher energy density than ethanol and has similar properties to gasoline [167,168].

The industrial acetone-butanol-ethanol (ABE) fermentation was the second largest fermentation process in history behind ethanol fermentation, using sugar or starch utilising solventogenic clostridia as Clostridium acetobutylicum, C. beijerinckii, C. saccharobuylicum, or C. saccharoperbutylacetonicum [167,169]. While this process was replaced by more commercially viable petroleum chemical plants after World War II and only continued in limited volumes in politically isolated countries such as China, South Africa, or the former Soviet Union, the process has seen a major revival recently with over a million ton production capacity per annum [170,171]. A few acetogenic strains have also been identified to produce butanol.

C. carboxidivorans or strain "P7" was isolated in 2005 from a lagoon settlement, and can grow autotrophically with $\mathrm{H}_{2}$ and $\mathrm{CO}_{2}$, or $\mathrm{CO}$ as substrate, or heterotrophically with simple sugars, having an optimal growth temperature of $37{ }^{\circ} \mathrm{C}-40{ }^{\circ} \mathrm{C}$ [172]. Products include acetate, ethanol, butanol and butyrate. Draft genome sequences are available for C. carboxidivorans [173,174], which contain the genes of the reductive acetyl-CoA pathway as well as enzymes for the conversion of acetyl-CoA into 
butanol and butyrate. Bruant et al. found the strain contains a plasmid and a butanol pathway similar to that of C. acetobutylicum [101]. The two-carbon acetyl segment of acetyl-CoA is converted to the four carbon butyryl-CoA through thiolase, 3-hydroxybutyryl-CoA dehydrogenase, crotonase, and butyryl-CoA dehydrogenase as in $\mathrm{ABE}$ fermentation organism $C$. acetobutylicum, while CoA transferase genes for acetone production are absent in C. carboxidivorans [93]. Butyryl-CoA is then converted to butyrate and butanol in a similar manner to acetate and ethanol from acetyl-CoA; enzymes such as alcohol dehydrogenase are often unspecific and act to produce both butanol and ethanol. C. carboxidivorans has been explored for the production of ethanol $[175,176]$ as well as the production of butanol [101].

C. scatologenes was isolated from soil in 1925 but the type strain was not originally described as acetogenic [177]. Although acetate is the primary end product, butyrate is also produced from sugars [177]. C. scatologenes has an optimal growth temperature of $37^{\circ} \mathrm{C}-40^{\circ} \mathrm{C}$ [172].

C. drakei was isolated from an acidic coal mine pond [172] and is similar to C. carboxidivorans and C. scatologenes. Originally classified as strain C. scatologenes SL1 [172,177], C. drakei has an optimal growth temperature of $37^{\circ} \mathrm{C}$.

B. methylotrophicum was isolated from a sewage digester and has an optimal growth temperature of $37{ }^{\circ} \mathrm{C}$ [178]. Products include acetate, ethanol, butyrate and butanol [179]. The CO strain of B. methylotrophicum was the first anaerobe shown to use CO as a sole energy and carbon source [180], and in 1991 was shown to produce butanol from CO [181]. Recently it has been investigated for the production of butanol from syngas [38]. Unlike the other organisms described, B. methylotrophicum is classified as a Risk Group 2 microorganism [182]. Genes for butanol production are unknown but expected to be similar to those found in $\mathrm{ABE}$ fermentation organism C. acetobutylicum.

\subsection{2,3-Butanediol}

2,3-Butanediol (23BD) is a high value chemical used as a precursor in the manufacture of industrial solvents such as methyl ethyl ketone (MEK) and 1,3-butadiene. Its downstream products have a global market of approximately $\$ 43$ billion per annum, and it is traditionally produced petrochemically [54].

Only recently, it was shown that C. autoethanogenum, C. ljungdahlii and " $C$. ragsdalei" are able to produce 23BD using steel mill waste gas as a sole source of carbon and energy, and a correlation was demonstrated between mRNA accumulation from 23BD biosynthetic genes, and 23BD production [54]. It was concluded that these results demonstrate that acetogens can be used for the production of pyruvate derived products such as 23BD. Acetyl-CoA can be converted into pyruvate via a pyruvate:ferredoxin oxidoreducatase (pyruvate synthase). From there, the three principal enzymes involved in the production of 23BD from the intermediate pyruvate are acetolactate synthase, acetolactate decarboxylase, and 23BD dehydrogenase [54]. 


\section{Fermentation and Bioreactor Optimisation}

Product synthesis rates and ethanol to acetate ratios initially described in the literature for gas fermenting organisms are often poor from a commercial perspective [160,183,184], and thus factors including nutrient media, $\mathrm{pH}$, temperature, and bioreactor design have been optimised in order to enhance these $[185,186]$.

Nutrient media for gas fermenting organisms must include minerals, vitamins, metal co-factors and a reducing agent. It has been hypothesised that non-growth-promoting conditions will improve the production profile, with solventogenesis favoured when cells are in the resting state [164]. This can be induced through transferring the cells to nutrient-limited media; for example, Cotter et al. found that nitrogen limitation led to improved ethanol production in C. autoethanogenum [164]. In addition, reducing agents have been shown to improve the product profile; this is likely to be because of the resulting increase in cellular NADH concentration which favours alcohol production through NADH-dependent pathways [187]. For example, a recent study of "C. ragsdalei" found that the addition of methyl viologen promoted solventogenesis, with the production of $1.3 \mathrm{~g} \mathrm{~L}^{-1}$ ethanol compared with $0.51 \mathrm{~g} \mathrm{~L}^{-1}$ with no added reducing agent [188]. The cost of fermentation media is also important due to the large volumes used at a commercial scale. Researchers have successfully investigated the use of low cost media components such as cotton seed extract or corn steep liquor to replace standard, more costly, vitamin and mineral media components $[158,189]$.

The inclusion of metal co-factors in fermentation media has also been demonstrated to improve microbial productivity. For example, nickel is an important co-factor for enzymes such as $\mathrm{CO}$ dehydrogenase and acetyl-CoA synthase, and has been shown to improve CO uptake and ethanol production in gas fermentation [186,190]. The impact of various trace metals on ethanol production was investigated in "C. ragsdalei", with the finding that removing $\mathrm{Cu}^{2+}$ from the medium and increasing concentrations of $\mathrm{Ni}^{2+}, \mathrm{Zn}^{2+}, \mathrm{SeO}_{4}^{-}$, and $\mathrm{WO}_{4}{ }^{-}$improves ethanol production, with a corresponding increase in activity of key Wood-Ljungdahl pathway metalloenzymes [155].

$\mathrm{pH}$ has been one of the most important factors in improving the activity of gas fermenting organisms due to its effect on product composition. Studies have shown a shift from acidogenesis to solventogenesis as fermentation $\mathrm{pH}$ is lowered, allowing the increased production of ethanol and other highly reduced products [153,191]. It is hypothesised that these organisms shift to the production of alcohol as the primary fermentative product in order to mitigate potentially dangerous drops in $\mathrm{pH}$ that result from accumulating acetic acid in their environment. Optimal $\mathrm{pH}$ varies depending on the organism; for example, $\mathrm{pH} 4.74$ was found to be optimal for ethanol production by C. autoethanogenum [163], while in " $C$. ragsdalei" it was shown that a $\mathrm{pH}$ below 6.0 was not associated with elevated ethanol concentrations [157].

Temperature is also important for fermentation optimisation as it influences both microbial productivity and substrate gas solubility. Optimum growth temperatures for the respective organisms are outlined in Section 5, with mesophilic organisms ranging from $30{ }^{\circ} \mathrm{C}-40{ }^{\circ} \mathrm{C}$ and thermophilic organisms ranging from $55{ }^{\circ} \mathrm{C}-60{ }^{\circ} \mathrm{C}$. Although the increased temperature required by thermophilic organisms reduces gas solubility, the effect on gas to liquid mass transfer rates may be mitigated by a decrease in viscosity. 
Finally, bioreactor design is important for gas fermentation because of its role in facilitating the mass transfer of $\mathrm{CO}$ and $\mathrm{H}_{2}$ from the gas phase into the microbial cell. The key objective of bioreactor design is thus to provide a high gas-liquid mass transfer efficiency of syngas into the fermentation broth, while allowing process scale-up and low operation costs. A range of reactor designs was recently reviewed [29], and approaches to enhancing gas solubility include increased pressure, specific fluid flow patterns, the use of microbubbles, and impellers designed to enhance bubble break up [192]. Designs which provide the highest volumetric mass transfer rates are generally not the most efficient due to their need for increased power consumption. Thus, mass transfer performance is more usefully described as the volumetric mass transfer coefficient per unit power input $\left(k_{\mathrm{L}} \mathrm{a} \mathrm{P}_{\mathrm{g}}^{-1}\right)$ [192]. Munasinghe \& Khanal compared the volumetric mass transfer coefficient $\left(k_{\mathrm{L}} \mathrm{a}\right)$ over eight different reactor configurations, reporting the highest $k_{\mathrm{L}} \mathrm{a}$ in an air-lift reactor combined with a $20 \mu \mathrm{m}$ bulb diffuser [193]. In a study of stirred tank reactors (STRs) using different impeller designs, Ungerman \& Heindel found that a dual Rushton-type impeller design had the highest $\mathrm{k}_{\mathrm{L}} \mathrm{a}$, but that dual impeller designs with an axial flow impeller as the top impeller had the highest $k_{\mathrm{L}}$ a $\mathrm{P}_{\mathrm{g}}^{-1}$ [192].

The majority of published studies on syngas fermentation have been carried out using bench-top scale continuous stirred tank reactors (CSTRs), with one study looking at a pilot scale $100 \mathrm{~L}$ fermenter [159]. However, options being considered by gas fermentation companies include bubble column, gas lift, trickle-bed, immobilised cell, and microbubble reactors [185,194,195]. For example, one group of patented reactor designs includes immobilised hollow fibre membranes developed by Coskata [196-199]. In one embodiment, a microporous layer maintains a biofilm containing the fermentation organism, and an outer-facing liquid-impermeable layer allows substrate gas to be transferred through to the liquid phase [198]. This solution allows gas to directly make contact with the fermentation organism, avoiding the need for gas to first transfer into the liquid medium.

\section{Strain Improvement}

Recently, metabolic engineering and synthetic biology techniques have been applied to gas fermentation organisms. This work strives to improve microbial productivity and robustness, and to introduce pathways for the commercial production of increasingly energy dense fuels and more valuable chemicals. Over the past two decades genetic techniques for clostridia, such as antisense RNA strategies [200], reporter gene systems [201-204], inducible promoter-repressor systems [205,206], and several double-crossover homologous recombination strategies [207-212], have been developed. More recently, integration based techniques such as ClosTron [213-215], as well as marker-less integration methods [216], have been applied to C. acetobutylicum and other species such as the cellulolytic $C$. thermocellum. Several review articles have been published recently that give a detailed overview of the developed tools [92,171,217]. Until the last five years there was a notable lack of techniques and tools allowing chromosomal manipulation in gas fermentation organisms. The recent availability of genome sequences for gas fermentation organisms (see Section 5) combined with these new molecular biology techniques and transformation protocols developed specifically for clostridia has made the direct modification of gas fermentation organisms possible.

The improvement of the robustness, productivity and ethanol to acetate ratios of gas fermenting organisms has been achieved through random mutagenesis combined with high-throughput screening 
for desired characteristics. For example, Coskata reported to have advanced undisclosed strains through mutagenesis and clonal screening [218], and C. ljungdahlii mutant strain OTA-1 has been isolated that produces approximately 2-fold more ethanol than the type strain [219]. Notably, there are no published reports of improved productivity of gas fermentation organisms through targeted genetic modification; this is likely to change with recent advances in genome sequencing and developments of genetic tools for gas fermentation organisms.

The use of metabolic engineering to integrate new pathways has been reported in three gas fermentation organisms [46,220]: C. ljungdahlii and C. autoethanogenum, for the production of the biofuel butanol [91,220], and C. aceticum, for the autotrophic production of the chemical acetone [221].

C. ljungdahlii has been modified with butanol biosynthesis genes $t h l A, h b d, c r t, b c d$, adhE and bdhA from ABE model organism C. acetobutylicum [91]. Genes were introduced through electroporation using a pIMP1 based shuttle plasmid and their expression led to the formation of up to $2 \mathrm{mM}$ butanol from synthesis gas. Although the produced butanol was largely metabolised by C. ljungdahlii at the end of the growth phase, forming butyrate, further genetic modification was proposed to improve butanol yield [91]. In a patent from LanzaTech, production of butanol as the main fermentation product has been described with C. ljungdahlii and C. autoethanogenum [220].

$C$. aceticum has been modified to produce acetone using a mix of acetone genes from C. acetobutylicum (adc, $\operatorname{ctf} A, \operatorname{ctf} B$, and thlA) and newly identified genes (encoding a thioesterase from Bacillus subtilis, and gene $y b g C$, an acyl-CoA thioesterase from Haemophilus influrenzae) $[46,221,222]$. Again, electroporation and the shuttle vector pIMP1 have been used. The recombinant $C$. aceticum strain produced $8 \mathrm{mg} \mathrm{L}^{-1}$ of acetone with clostridial genes on $80 \% \mathrm{H}_{2}$ and $20 \% \mathrm{CO}_{2}$ as substrate using a sugar grown pre-culture [221]. It was proposed that, with genome information, the inactivation of pathways for the formation of by-products would allow improvement in acetone yield [46].

Through synthetic biology, routes to advanced biofuels such as isobutanol and farnesene have been demonstrated in E. coli and yeast [223], and as genetic tools are further developed there is the potential for these approaches to be implemented with acetogenic bacteria. Another intriguing strategy is to transplant the genes for gas utilisation into more genetically malleable organisms. For example, genes of the Wood-Ljungdahl pathway have already been introduced into E. coli [224,225] and C. acetobutylicum [226] with minimal $\mathrm{CO}_{2}$ uptake observed without transfer into products. The complexity of multi-subunit enzymes involved in the Wood-Ljungdahl pathway with their labile iron sulphur clusters and the number of required co-factors is especially challenging and will require much work, particularly for more distant organisms such as E. coli. For methanogens, it was estimated that over 200 genes are required for production of methane from $\mathrm{CO}_{2}$ and $\mathrm{H}_{2}$ [227].

These efforts will greatly benefit from systems biology approaches and the creation of genome-scale metabolic models. While only a single acetogen had been sequenced before mid-2010, several genome sequences have since been released [91,101,102,144,173,174,228]. However, only very few transcriptomic studies have been published to date [54,176], looking at certain sets of genes rather than gene expression on a global basis. With advances in "Omics" technologies and further reduction in the cost of sequencing, this will certainly change in the future. 


\section{Challenges}

Commercial interest in gas fermentation has increased significantly over the past six years. This is illustrated by an increase in related research (Figure 2a) and patent filings (Figure 2b) over this time period, and is demonstrated by the emergence of several companies seeking to commercialise the process for the production of commodity fuels and chemicals.

Despite this increase in commercial interest, biomass gasification followed by syngas fermentation has yet to be achieved on a commercial scale. One of the principal technical challenges associated with commercialisation is the successful scale-up of this process combination from pilot-scale to a commercial level [150].

Figure 2. (a) Gas fermentation-related academic literature versus time (SciVerse ${ }^{\circledR}$ Scopus ${ }^{\circledR}$ [229] keyword search: syngas fermentation and/or carbon monoxide with Clostridium, Acetobacterium, Moorella, Carboxydotrophic and/or acetogenic); (b) Gas fermentation-related patent filings versus time (Thomson Innovation ${ }^{\circledR}$ [230] keyword search: syngas fermentation and/or carbon monoxide with Clostridium, Acetobacterium, Moorella, Carboxydotrophic and/or acetogenic).

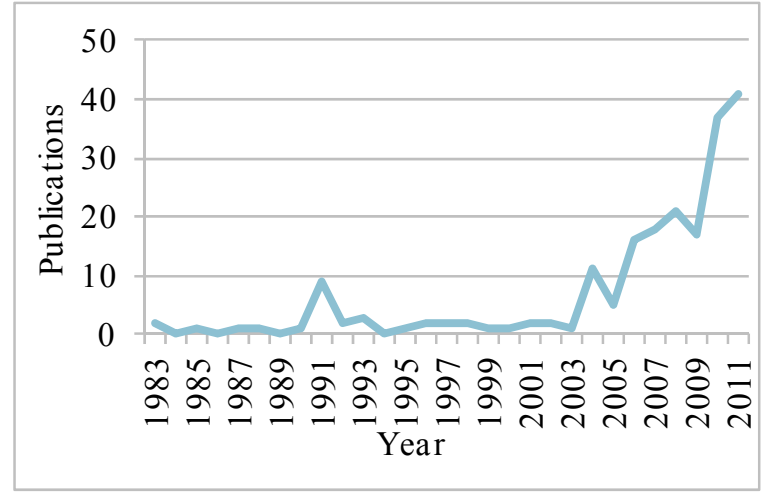

(a)

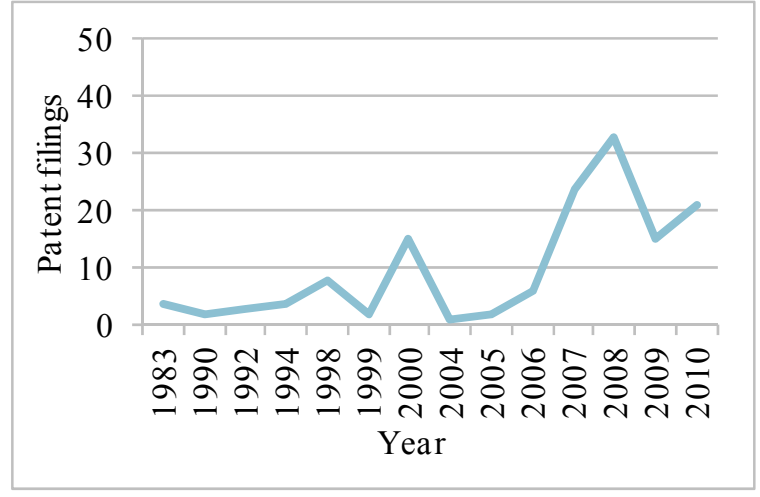

(b)

\subsection{Gasification and Gas Clean-Up}

The technical readiness of biomass gasification technology at scale and predicted high costs involved in producing biomass syngas are key challenges. As outlined in Section 3, gasification technology has a long history of development, and is used commercially to produce syngas from coal for downstream thermo-catalytic processing. However, biomass gasification for the purpose of commercial synthesis gas fermentation is relatively novel and an economically feasible and reliable process has yet to be proven at a commercial scale. Although work over the past decade has shown promising advances in gasification [59], one key challenge may be the consistent production of gas free from contaminants.

Microbial catalysts are robust and can tolerate a range of impurities in synthesis gas. Consequently, the microbial fermentation of synthesis gas does not require the strict standard of synthesis gas purity demanded by the thermochemical Fischer-Tropsch route. However, if the concentration of certain impurities is too high, both bacterial growth rates and product formation can be affected [231]. Studies have shown that nitric oxide, $\mathrm{H}_{2} \mathrm{~S}$ and tars are potential cellular and enzyme inhibitors, affecting 
product formation and cell growth [232,233]. By optimising pre-treatment and gasification in a feedstock-dependent manner the formation of impurities can be minimised, reducing the need for expensive gas clean-up. However, since impurities generated can influence variables involved in the fermentation process, including $\mathrm{pH}$, osmolarity, and redox potential, and can directly inhibit enzymes and contribute to cell toxicity, a gas clean-up step is important to ensure a clean syngas is produced which does not contain components which will negatively interfere with the fermentation process. Xu, Tree \& Lewis have reviewed all recorded impurities generated during the gasification of biomass and explored their relative risk of accumulation and potential negative effect on the fermentation process [62]. They identified that carbonaceous species (including methane and tars), nitrogeneous species (ammonia, hydrogen cyanide, mono-nitrogen oxides) and sulphurous species (sulphur dioxide, hydrogen sulphide, carbonyl sulphide) are the most prevalent impurities, and explored the mass transfer rates of these impurities to establish their availability in the bioreactor.

Tars can be defined as hydrocarbons with a molecular weight higher than benzene, and are a key impurity produced during the pyrolysis stage of the gasification process [234]. Their formation is heavily dependent on the nature of the gasification process, and thus preventing their formation by optimising this process is the best avenue for reducing tar levels. Tars promote cell dormancy and affect product distribution, although in a study using C. carboxidivorans $\mathrm{P} 7^{\mathrm{T}}$ as the microbial catalyst it was hypothesised that cells were able to adapt to tars and grow in their presence following prolonged exposure [233].

Nitric oxide present in syngas was demonstrated to inhibit hydrogenase and affect both cell growth and metabolism at gas concentrations above $40 \mathrm{ppm}$ [232]. Hydrogenase is used to oxidise molecular hydrogen, and provides electrons for anaerobic metabolism. While the presence of nitric oxide can increase ethanol production rates, it reduces the overall carbon conversion efficiency of the process. This is because it reduces the available carbon for product formation, as $\mathrm{CO}$ is used instead of $\mathrm{H}_{2}$ in the production of electrons. Nitric oxide has been found in synthesis gas from switchgrass biomass at $150 \mathrm{ppm}$, and thus requires clean-up [233]; nitric oxide can be scavenged using sodium hypochlorite, potassium permanganate or sodium hydroxide [235-237].

Ammonia $\left(\mathrm{NH}_{3}\right)$ inhibits bacterial cell growth by increasing osmolarity; furthermore, the ammonium ion has an inhibitory effect on hydrogenase, even at low concentrations [62]. Despite this, ammonia is also a source of nitrogen for the bacteria and readily consumed. Most nitrogen found in biomass is converted to $\mathrm{NH}_{3}, \mathrm{~N}_{2}$, and some $\mathrm{HCN}$ and $\mathrm{NO}_{2}$ during the gasification process, with $60 \%-80 \%$ of the nitrogen in biomass converting to $\mathrm{NH}_{3}$ [238]. Because of the high solubility of ammonia, the ammonium ion has been shown to accumulate in the bioreactor and thus low levels of ammonia in the synthesis gas may still accumulate to levels which can inhibit the biocatalyst [62]. Conventionally, ammonia has been cleaned using wet scrubbing technology where it is dissolved in water droplets. This is what is generally used in biomass gasification processes; however, catalytic hot-gas technology, which does not require gas cooling, has recently been explored [239].

Studies investigating hydrogen sulphide $\left(\mathrm{H}_{2} \mathrm{~S}\right)$ have shown that, although gas fermentation organisms can tolerate a certain level of sulphur gas, substrate uptake and cell growth are both significantly affected once this threshold is passed [39,240]. For example, Grethlein et al. observed severe cell growth inhibition with $B$. methylotrophicum in the presence of greater than $2 \% \mathrm{H}_{2} \mathrm{~S}$ gas, with metabolism favouring acetate production at the expense of biomass growth [240]. The formation 
of hydrogen sulphide shows strong temperature dependence [241] and varies highly depending on feedstock, increasing with increased feedstock elemental sulphur composition. An investigation with C. acetobutylicum found that there was no significant inhibition of growth or butanol production below $0.9 \mathrm{mmol} \mathrm{L}^{-1}$ sulphide, which corresponds to $1.2 \% \mathrm{H}_{2} \mathrm{~S}$ gas concentration at $\mathrm{pH} 5.0$ [240]. This level of tolerance falls above what has been typically observed in biomass syngas and consequently gas fermentation syngas does not require the same rigorous clean-up of sulphides as the Fischer-Tropsch process, which requires amounts of less than $0.1 \mathrm{ppm}$ [39].

Although it has not been reported in syngas generated from biomass, oxygen is a notable poison of acetogens. Gas fermenting organisms are unable to grow in oxic conditions because enzymes involved in the reductive acetyl-CoA pathway are poisoned by very low levels of oxygen [105]. For example, pyruvate-ferredoxin oxidoreductase catalyses a pyruvate- $\mathrm{CO}_{2}$ exchange reaction: its exposed iron-sulphur sites are susceptible to oxidative inactivation, leading it to be one of the most oxygen sensitive enzymes known [121,242,243]. Interestingly, some acetogens have an oxygen detoxification pathway which allows them to tolerate certain levels of oxidative stress [244]. This has been demonstrated physiologically throughout the Clostridium genus, with species such as Clostridium butyricum and $C$. acetobutylicum being shown to resume growth following oxygen consumption, with no lasting damage. Furthermore, some research suggests that these species are able to continue growth under microoxic conditions [245]. This indicates that these acetogens are able to both metabolise $\mathrm{O}_{2}$ and scavenge derived $\mathrm{O}_{2}$ species such as $\mathrm{H}_{2} \mathrm{O}_{2}$. Kawasaki et al. found that the peptide transcripts of A-type flavoprotein homologue and novel type rubrerythrin homologue in C. acetobutylicum were upregulated within ten minutes of an oxygen shock [246]. Other enzymes thought to be involved in oxygen metabolism in acetogens include NADH-oxidase, superoxide dismutase, and rubrerythrin [244,247]. Karnholz et al. found that acetogens including $M$. thermoacetica and A. woodii grew in non-reduced liquid medium containing small amounts of $\mathrm{O}_{2}$ gas; furthermore, they found that increasing this amount of $\mathrm{O}_{2}$ caused an increase in the lag growth phase, with a decrease in final biomass achieved [244]. In this case they found that in micro-oxic conditions, bacteria including $M$. thermoacetica and $A$. woodii were metabolically consuming oxygen.

Traditional solutions to identify oxygen contamination are not practical in gas fermentation on a commercial scale. Diagnosis of contamination could be carried out by monitoring the gene expression profile of genes involved in the oxygen detoxification pathway; furthermore, the robustness of gas fermenting bacteria in the presence of oxygen could be improved through genetic manipulation. For example, $C$. acetobutylicum has been engineered to improve its aero-tolerance by introducing glutathione biosynthetic capability [248]. Although the chance of oxygen being present in biomass syngas is minimal, oxygen can be removed by passing the syngas through a bed of reduced copper, or through a palladium-based oxygen removal catalyst. If the syngas contains high levels of acetylene, the palladium option is preferred as copper may react and cause explosive copper acetylides.

Impurities in the synthesis and subsequent gas clean-up steps utilised will vary depending on the biomass feedstock [233]. Some gas cleaning techniques include tar cracking, wet cleaning, the use of active carbon and $\mathrm{ZnO}$ [249]. Tar cracking techniques include catalytic cracking, thermal cracking, plasma cracking, scrubbing with water, and scrubbing with oil [234]. Wet gas cleaning is a conventional method where synthesis gas is in contact with fine droplets of water in a counter or co-current flow. Here, water soluble substances are dissolved, including nitric oxide and ammonia. 
However, new developments using catalytic-based hot-gas cleaning appear to be superior in terms of energy efficiency in removing both tar and ammonia from the synthesis gas [239], and $\mathrm{ZnO}$ and activated-carbon filters are a good method for removing $\mathrm{H}_{2} \mathrm{~S}$ and other inorganic impurities [249]. Ahmed et al. found that synthesis gas from switchgrass produced in a fluidised bed reactor could be cleaned with a cyclone, $10 \%$ acetone scrubbing bath and $0.025 \mu \mathrm{m}$ filters. This process sufficiently cleaned the syngas so that the biocatalyst was viable and the product profile was unaffected, compared with results from a synthetic gas stream [233].

\subsection{Fermentation and Bioreactor Design}

The fermentation step itself also faces a number of technical challenges including scale-up and mass transfer limitations and risks involved with the biocatalyst. For commercial viability, this fermentation must occur reliably with high conversion efficiencies and on a large scale. Compared to aerobic processes, cell concentrations in anaerobic fermentations are usually lower as ATP is limited. While it is desirable to have most of the carbon going into products rather than biomass, a certain cell concentration is necessary to achieve high production rates. This can be a challenge, and there are several strategies to overcome this issue, starting from media optimisation to allow increased biomass formation, to cell recycling or cell immobilisation to retain cells that have been successfully applied to other anaerobic or clostridial processes [250]. For example, cell recycling has been shown to improve cell concentration and productivity in the ABE process. [251]. Cell recycling, usually achieved with a semi-permeable membrane, is an interesting approach as it allows high cell concentrations and clean permeates for further separation [250]. However, membranes are prone to fouling and need to be replaced regularly which makes a continuous process more difficult. Immobilisation of cells, either through covalent bond formation, entrapment or in biofilms is another way to achieve high cell concentration and may also offer an advantage of increased tolerance [250]. However, immobilisation of cells usually requires some time in which production is limited, but on the other hand may also offer longer runs compared to a non-immobilised process. Unlike the batch ABE process where nutrients are pre-loaded, gas fermentation is typically a continuous process with gas constantly being seeded, requiring consistency [159]. One of the biggest challenges at scale is to ensure high mass transfer rates to ensure transfer of gas into the aqueous phase from where it can be accessed by the microbes [193], thought to be a rate-limiting step [252]. This is because $\mathrm{CO}$ and $\mathrm{H}_{2}$ are relatively insoluble, yet as the sole source of carbon and energy, a considerable amount is required for product synthesis; for example, the stoichiometric substrate-to-product ratio of carbon monoxide to ethanol is 6:1 [150]. At a lab scale usually continuous stirred tank reactors (CSTRs) are used to ensure high mass transfer, but their energy inefficiency brings up the need for different designs at scale. Specialised bioreactor designs and other techniques discussed in Section 6 seek to solve this problem.

Secondly, there are risks associated with the microbial catalyst, including previously-discussed poisoning (by oxygen or other contamination), and bacteriophage infection [253]. Bacteriophage infection of biocatalyst, a serious problem associated with other microbial fermentation processes, has yet to be reported with synthesis gas fermentation. As with gas contaminants, bacteriophage infection may affect microbial productivity to different extents, with symptoms difficult to diagnose. Similarities can be seen with the commercial acetone-butanol-ethanol (ABE) fermentation process, which 
underwent significant commercial development and use from 1916-1983 [169]. In this batch process, related sugar-fermenting clostridia such as C. acetobutylicum and Clostridium beijerinckii were used to anaerobically produce acetone, butanol and ethanol from starch. Bacteriophage infection was a major problem in the $\mathrm{ABE}$ fermentation industry, with infection reducing microbial growth rates and productivity, and shutting down plants at multiple points in history [254]. Moreover, despite preventative efforts being taken, the incidence of bacteriophage infection remained widespread. In 1923 the first reported problem during ABE fermentation occurred when the solvent yield of C. acetobutylicum halved at a plant run by Commercial Solvents Corporation (CSC); when bacteriophage infection was eventually established as the cause, an entirely new plant was constructed 200 miles away [254]. Symptoms of phage infection include slow fermentation rates with reduced yields, as well as changes in cell morphology and population [254]. Techniques used to avoid phage infection include improved culture practise and plant hygiene, and the creation of phage-immunised strains through the serial transfer of phage-resistant mutants [254].

Compared to $\mathrm{ABE}$ fermentation, the gas fermentation process is potentially not as prone to phage infection because most bacteriophage would probably be thermally inactivated by the extreme heat of the gasification step. The fermentation process occurs on minimal media, with no sugar or plant matter entering the system, unlike in ABE fermentation where molasses was used as feedstock. This reduces the chance of the introduction of phage and, coupled with the presence of generally poisonous $\mathrm{CO}$ as a carbon source, reduces risk of bacterial contamination. Although no instances of bacteriophage infection have been reported, this does not indicate resistance. Almost all bacterial species investigated have been found susceptible to infection by at least one phage and, despite most gas fermentation organisms having at least one methylation system to protect against foreign phage DNA, phage have infected other clostridia [253]. Infection could be economically damaging in a commercial process, potentially requiring an entire plant to be taken offline so that a decontamination and sterilisation process can be carried out. This is therefore a noteworthy potential threat to commercialisation of the gas fermentation process.

\subsection{Downstream Processing}

Most technologies used during downstream product separation are mature and thus are unlikely to pose technical or commercial challenges. However, as gas fermentation has lower reported production titres compared with traditional fermentations, more energy is potentially required for downstream product recovery. Mature technologies are available for the distillation of ethanol and butanol [255], and are carried out largely in the same manner as for conventional fermentation. However, the recovery of 2,3-butanediol has not yet been established at scale [256]. To improve process efficiency and reduce cost it is important that the process is run in a continuous closed loop. Thus, the downstream product separation step must allow, for example, a water and nutrient recycle.

As discussed, the majority of the challenges associated with gasification and gas clean-up, fermentation and bioreactor design, and downstream processing have been solved on an individual basis at a small scale. However, the integration of all of these components, which encompass instances of novel technology, at a commercial scale is challenging, and is a significant barrier to commercialisation. 


\section{Commercialisation}

INEOS Bio, Coskata and LanzaTech are three companies exploring the commercialisation of gas fermentation for the production of liquid fuels. The first patents in the area of gas fermentation were filed by J.L. Gaddy of the University of Arkansas in Fayetteville [183,257,258]. Gaddy also pioneered the transfer of this technology from academia into industry with the creation of Bioengineering Resources Inc. (BRI) [259,260]. BRI operated a pilot unit from 2003 and the technology was acquired in 2008 by INEOS, a major multinational chemical firm [261].

INEOS Bio (http://www.ineosbio.com) was created as a subsidiary of INEOS in 2008, and at their pilot plant reported a production rate of 100 gallons of ethanol per dry ton of feedstock using proprietary isolates of $C$. ljungdahlii as the biocatalyst [185,262,263]. In 2011 INEOS Bio began construction of their first commercial scale plant, the Indian River BioEnergy Center in Florida [264]. Currently in commissioning with plans to begin operation in the third quarter of 2012, this plant is designed to produce ethanol from yard, vegetative and household waste, and is also projected to produce six megawatts (gross) of electricity from unused syngas and recovered heat [265]. The plant has a planned capacity of 300 dry tons per day, producing 8 million gallons of ethanol per year [266]. A second commercial plant, Seal Sands based in Teesside, UK is in design [267]. Conditional on financing, INEOS Bio expect it to be completed in 2013 with similar bioethanol and power production rates to the Florida plant [259].

Coskata, Inc. (http://www.coskata.com) was founded in 2006 in Warrenville, IL, USA using technology and organisms $C$. ragsdalei and C. carboxidivorans licensed from Oklahoma State University and the University of Oklahoma [218]. Coskata has also disclosed the identification and development of a related proprietary bacterium for ethanol production, "Clostridium coskatii" [268]. Coskata has operated its gas fermentation technology at a demonstration plant in Madison, PA since October 2009 [218] with syngas produced from wood biomass and municipal solid waste using a plasma gasification process developed by Westinghouse Plasma Corporation [269]. Coskata reported that they were constructing a commercial plant in Alabama for the conversion of wood chips and waste to ethanol, with a planned production capacity to 16 million gallons of ethanol per year, to be scaled up to 78 million gallons of ethanol per year [218]. This plant will not use the Westinghouse Plasma Corporation gasification technology used at the demonstration plant, and instead will use an indirect biomass gasifier [218], and Coskata published an expected yield of 100 gallons of ethanol per bone dry ton of softwood, with unsubsidised cash operating costs of up to USD\$1.50 per gallon [218]. In December 2011 Coskata filed an S-1 registration statement for a proposed USD \$100 million initial public (IPO) offering to fund this plant [218]. However, in July 2012 the company announced a shift in strategy towards the construction of a commercial plant funded by private strategic investors which uses reformed natural gas as the sole feedstock [270].

LanzaTech (http://www.lanzatech.co.nz) was founded in Auckland, New Zealand in 2005 and their commercialisation route to-date has focused on the use of synthesis gas and CO-rich industrial off-gases to produce ethanol and 2,3-butanediol, using a proprietary strain of C. autoethanogenum [271]. The ability to produce chemicals such as 2,3-butanediol and butanol [54,220] as well as traditional fuels like ethanol by gas fermentation organisms is a distinct feature of the LanzaTech technology. LanzaTech recently signed a joint venture agreement with nylon producer INVISTA for development 
of bio-based butadiene from CO [272]. LanzaTech have been running a pilot-scale plant using steel mill off-gases at the BlueScope Steel facility in New Zealand since 2008 [273], and have built a pre-commercial 100,000 gallon-per-year demonstration plant in partnership with BaoSteel in Shanghai, China for the production of ethanol from steel mill off-gases [49]. Construction of another steel mill-based plant has begun with Shougang Group, through a joint venture to develop a demonstration plant located at a Shougang steel mill [50]. Finally, LanzaTech have acquired the foreclosed Range Fuels plant in Soperton, Georgia in order to produce biomass synthesis gas from wood residues [274].

\section{Summary}

Gas fermentation is a second generation biofuel technology currently in development with tremendous feedstock flexibility. In this process, biomass is gasified into syngas which is then fermented by acetogenic bacteria. These gas fermenting organisms utilise the Wood-Ljungdahl pathway to produce fuels and chemicals including acetate, ethanol, butanol and 2,3-butanediol. Over the past five years considerable research has been done in the area of gas fermentation, with the isolation and development of new gas fermenting organisms, development of the gasification process, and research into different reactor designs.

The conversion of lignocellulosic biomass to biofuels through gas fermentation has yet to be demonstrated at scale. Multiple instances of novel technology make up the process, and companies seeking to commercialise the process have often chosen to partner with other parties to focus on different areas of technology; for example, partnerships between gas fermentation companies and biomass gasification companies. Furthermore, two companies are first seeking to commercialise a gas fermentation process from already-present gas streams, with LanzaTech using industrial waste gas streams [50], and Coskata using natural gas as a first commercial feedstock [270]. This removes the risk involved in novel biomass gasification technology, and will subsequently allow syngas generated from lignocellulosic biomass to be swapped in as feedstock with the creation of an integrated process.

Metabolic engineering and synthetic biology techniques show great promise for the improvement of the gas fermentation process, and the first steps using advanced genetic tools have only recently been taken. These approaches are paving the way for the development of an increasingly robust and efficient process, and will allow the production of increasingly energy dense fuels and more valuable chemicals. Most gas fermentation organisms are not very well characterised, especially when compared to $C$. acetobutylicum, the model organism used in ABE fermentation. The first genome sequence to be published for a gas fermentation organism was in 2008 [144], and subsequent advances made in the areas of metabolic engineering and synthetic biology will continue to accelerate.

Although other second generation technologies for the creation of fuels from lignocellulosic biomass are the focus of the majority of research and development, the advantages of gas fermentation have led to strong academic and commercial interest, as evident in the literature. As demonstration plants are commissioned, the nature of technological hurdles at scale will become more apparent, and the future of commercial gas fermentation will become clearer. 


\section{References}

1. Stern, N. The Economics of Climate Change: The Stern Review; Cambridge University Press: New York, NY, USA, 2007.

2. The European Parliament and the Council of the European Union. Directive 2009/28/EC on the promotion of the use of energy from renewable sources and amending and subsequently repealing Directives 2001/77/EC and 2003/30/EC. Available online: http://europa.eu/legislation_summaries/ energy/renewable_energy/en0009_en.htm (accessed on 14 December 2012).

3. Energy Independence and Security Act of 2007; 110th United States Congress: Washington, WA, USA, 2007.

4. Hertel, T.W.; Tyner, W.E.; Birur, D.K. The global impacts of biofuel mandates. Energy J. 2010, 31, 75-100.

5. Naik, S.N.; Goud, V.V.; Rout, P.K.; Dalai, A.K. Production of first and second generation biofuels: A comprehensive review. Renew. Sustain.Energy Rev. 2010, 14, 578-597.

6. Bailey, R. Another Inconvenient Truth: How Biofuel Policies Are Deepening Poverty and Accelerating Climate Change; Oxfam International: Oxford, UK, 2008.

7. Greenpeace European Unit. Europe's Biofuels Plans Driving Social and Environmental Destruction. Available online: http://www.greenpeace.org/eu-unit/en/News/2010/driving-todestruction-08-11-10 (accessed on 15 August 2012).

8. Graziano da Silva, J. The US Must Take Biofuel Action to Prevent a Food Crisis. Available online: http://on.ft.com/QSyKBJ (accessed on 15 August 2012).

9. Hornby, C. U.S. Should Change Biofuel Policy to Avoid Food Crisis: U.N. Available online: http://www.reuters.com/article/2012/08/10/us-food-biofuels-fao-idUSBRE8790K420120810 (accessed on 15 August 2012).

10. Fargione, J.; Hill, J.; Tilman, D.; Polasky, S.; Hawthorne, P. Land clearing and the biofuel carbon debt. Science 2008, 319, 1235-1238.

11. Melillo, J.M.; Reilly, J.M.; Kicklighter, D.W.; Gurgel, A.C.; Cronin, T.W.; Paltsev, S.; Felzer, B.S.; Wang, X.; Sokolov, A.P.; Schlosser, C.A. Indirect emissions from biofuels: how important? Science 2009, 326, 1397-1399.

12. Bioenergy_Chances and Limits; German National Academic of Sciences Leopoldina: Halle, Germany, 2012.

13. Mitchell, D.; Kojima, M.; Ward, W. Considering Trade Policies for Liquid Biofuels; Special Report; Energy Sector Management Assistance Program: Washington, DC, USA, 2007.

14. Carney, B. Can the World Still Feed Itself? Available online: http://on.wsj.com/omahnc (accessed on 20 August 2012).

15. Thompson, A. Nestle Chief Calls for End to Using Food in Biofuel Production. Available online: http://uk.reuters.com/article/2012/08/19/uk-nestle-idUKBRE87I03W20120819 (accessed on 20 August 2012).

16. Naylor, R.L.; Liska, A.J.; Burke, M.B.; Falcon, W.P.; Gaskell, J.C.; Rozelle, S.D.; Cassman, K.G. The Ripple Effect: Biofuels, Food Security, and the Environment. Environ. Sci. Policy Sustain. Dev. 2007, 49, 30-43. 
17. Mitchell, D. A Note on Rising Food Prices. World Bank Development Prospects Group: Washington, DC, USA, 2008.

18. Ajanovic, A. Biofuels versus food production: Does biofuels production increase food prices? Energy 2011, 36, 2070-2076.

19. OECD-FAO Agricultural Outlook 2011-2020; Organisation for Economic Co-operation and Development (OECD) and the United Nation's Food and Agricultural Organization, 2011. Available online: http://www.oecd.org/site/oecd-faoagriculturaloutlook/ (accessed on 14 December 2012).

20. Murphy, R.; Woods, J.; Black, M.; McManus, M. Global developments in the competition for land from biofuels. Food Policy 2011, 36, S52-S61.

21. Tilman, D.; Hill, J.; Lehman, C. Carbon-negative biofuels from low-input high-diversity grassland biomass. Science 2006, 314, 1598-600.

22. Perlack, R.; Wright, L.; Turhollow, A.; Graham, R.; Stokes, B.; Erbach, D. Biomass as Feedstock for a Bioenergy and Bioproducts Industry: The Technical Feasibility of a Billion-Ton Annual Supply; U.S. Department of Energy: Washington, DC, USA, 2005.

23. World Energy Council 2010 Survey of Energy Resources. Available online: http://www.worldenergy.org/documents/ser_2010_report_1.pdf (accessed on 5 August 2012).

24. Metz, B.; Davidson, O.; Bosch, P.; Meyer, L. Contribution of Working Group III to the Fourth Assessment Report of the Intergovernmental Panel on Climate Change, 2007; Metz, B., Davidson, O., Bosch, P., Meyer, L., Eds.; Cambridge University Press: Cambridge, UK, 2007.

25. Saddler, J.N.; Mabee, W.E.; Simms, R.; Taylor, M. The Biorefinining Story: Progress in Commercialization of Biomass-to-Ethanol. In Forests in Development: A Vital Balance; Schlichter, T.; Montes, L., Eds.; Springer Netherlands: Dordrecht, The Netherlands, 2012; pp. 39-51.

26. Gnansounou, E.; Dauriat, A. Techno-economic analysis of lignocellulosic ethanol: A review. Bioresour. Technol. 2010, 101, 4980-4991.

27. Datta, R.; Maher, M.A.; Jones, C.; Brinker, R.W. Ethanol-the primary renewable liquid fuel. J. Chem. Technol. Biotechnol. 2011, 86, 473-480.

28. Wilkins, M.R.; Atiyeh, H.K. Microbial production of ethanol from carbon monoxide. Curr. Opin. Biotechnol. 2011, 22, 326-330.

29. Munasinghe, P.C.; Khanal, S.K. Biomass-derived syngas fermentation into biofuels: Opportunities and challenges. Bioresour. Technol. 2010, 101, 5013-5022.

30. Abubackar, H.N.; Veiga, M.C.; Kennes, C. Biological conversion of carbon monoxide: rich syngas or waste gases to bioethanol. Biofuels Bioprod. Biorefin. 2011, 5, 93-114.

31. Dry, M.E. The Fischer-Tropsch process: 1950-2000. Catal. Today 2002, 71, 227-241.

32. Tijmensen, M.; Faaij, A.; Hamelinck, C.; van Hardeveld, M. Exploration of the possibilities for production of Fischer Tropsch liquids and power via biomass gasification. Biomass Bioenergy 2002, 23, 129-152.

33. Davis, B.H. Fischer-Tropsch Synthesis: Reaction mechanisms for iron catalysts. Catal. Today 2009, 141, 25-33. 
34. Mirwald, J.W.; Inderwildi, O.R. Unraveling the Fischer-Tropsch mechanism: a combined DFT and microkinetic investigation of $\mathrm{C}-\mathrm{C}$ bond formation on Ru. Phys. Chem. Chem. Phys. 2012, 14, 7028-7031.

35. Fischer, F.; Tropsch, H. Process for the production of paraffin-hydrocarbons with more than one carbon atom. U.S. Patent 1746464, 11 February 1930.

36. Griffin, D.W.; Schultz, M.A. Fuel and chemical products from biomass syngas: A comparison of gas fermentation to thermochemical conversion routes. Environ. Prog. Sustain. Energy 2012, 31, 219-224.

37. Van Steen, E.; Claeys, M. Fischer-Tropsch catalysts for the biomass-to-liquid (BTL)-process. Chem. Eng. Technol. 2008, 31, 655-666.

38. Heiskanen, H.; Virkajärvi, I.; Viikari, L. The effect of syngas composition on the growth and product formation of Butyribacterium methylotrophicum. Enzyme Microb. Technol. 2007, 41, 362-367.

39. Vega, J.L.; Klasson, K.T.; Kimmel, D.E.; Clausen, E.C.; Gaddy, J.L. Sulfur gas tolerance and toxicity of CO-utilizing and methanogenic bacteria. Appl. Biochem. Biotechnol. 1990, 24/25, 329-340.

40. Gual, A.; Godard, C.; Castillón, S.; Curulla-Ferré, D.; Claver, C. Colloidal Ru, Co and Fe-nanoparticles. Synthesis and application as nanocatalysts in the Fischer-Tropsch process. Catal. Today 2012, 183, 154-171.

41. Sims, R.E.H.; Mabee, W.; Saddler, J.N.; Taylor, M. An overview of second generation biofuel technologies. Bioresour. Technol. 2010, 101, 1570-1580.

42. Mabee, W.E.; Gregg, D.J.; Arato, C.; Berlin, A.; Bura, R.; Gilkes, N.; Mirochnik, O.; Pan, X.; Pye, E.K.; Saddler, J.N. Updates on softwood-to-ethanol process development. Appl. Biochem. Biotechnol. 2006, 129-132, 55-70.

43. Taherzadeh, M.J.; Karimi, K. Pretreatment of lignocellulosic wastes to improve ethanol and biogas production: a review. Int. J. Mol. Sci. 2008, 9, 1621-1651.

44. Mosier, N.; Wyman, C.; Dale, B.; Elander, R.; Lee, Y.Y.; Holtzapple, M.; Ladisch, M. Features of promising technologies for pretreatment of lignocellulosic biomass. Bioresour. Technol. 2005, 96, 673-686.

45. Olson, D.G.; McBride, J.E.; Shaw, A.J.; Lynd, L.R. Recent progress in consolidated bioprocessing. Curr. Opin. Biotechnol. 2012, 23, 396-405.

46. Schiel-Bengelsdorf, B.; Dürre, P. Pathway engineering and synthetic biology using acetogens. FEBS Lett. 2012, 586, 2191-2198.

47. Dias, M.O.S.; Junqueira, T.L.; Jesus, C.D.F.; Rossell, C.E.V.; Filho, R.M.; Bonomi, A. Improving bioethanol production-Comparison between extractive and low temperature fermentation. Appl. Energy 2012, 98, 548-555.

48. Bacovsky, D.; Dallos, M.; Wörgetter, M. Status of 2nd Generation Biofuels Demonstration Facilities in June 2010; IEA Bioenergy Task 39; International Energy Agency (IEA): Paris, France, 2010; pp. 1-126.

49. LanzaTech Closes US \$55.8 Million Series C Round. Available online: http://www.lanzatech.co.nz/sites/default/files/imce_uploads/seriesc_lanzatech_final_for_release.pdf (accessed on 23 July 23, 2012). 
50. LanzaTech Chinese Steel Miller Commercializing LanzaTech's Clean Energy Technology. Available online: http://www.lanzatech.co.nz/sites/default/files/imce_uploads/shougangprvf.pdf (accessed on 1 August 2012).

51. Banerjee, S.; Mudliar, S.; Sen, R.; Giri, B.; Satpute, D.; Chakrabarti, T.; Pandey, R.A. Commercializing lignocellulosic bioethanol: technology bottlenecks and possible remedies. Biofuels Bioprod. Biorefin. 2010, 4, 77-93.

52. McKendry, P. Energy production from biomass (Part 3): Gasification technologies. Bioresour. Technol. 2002, 83, 55-63.

53. E4Tech. Review of Technologies for Gasification of Biomass and Wastes; NNFCC Project 09/008 Final Report; NNFCC: York Science Park, UK, 2009.

54. Köpke, M.; Mihalcea, C.; Liew, F.; Tizard, J.H.; Ali, M.S.; Conolly, J.J.; Al-Sinawi, B.; Simpson, S.D. 2,3-Butanediol production by acetogenic bacteria, an alternative route to chemical synthesis, using industrial waste gas. Appl. Environ. Microbial. 2011, 77, 5467-5475.

55. Skinner, K.A.; Leathers, T.D. Bacterial contaminants of fuel ethanol production. J. Ind. Microbiol. Biotechnol. 2004, 31, 401-408.

56. Mussatto, S.I.; Dragone, G.; Guimarães, P.M.R.; Silva, J.P.A.; Carneiro, L.M.; Roberto, I.C.; Vicente, A.; Domingues, L.; Teixeira, J.A. Technological trends, global market, and challenges of bio-ethanol production. Biotechnol. Adv. 2010, 28, 817-830.

57. Quintero, J.A.; Montoya, M.I.; Sánchez, O.J.; Giraldo, O.H.; Cardona, C.A. Fuel ethanol production from sugarcane and corn: Comparative analysis for a Colombian case. Energy 2008, 33, 385-399.

58. Madson, P. Ethanol distillation: the fundamentals. In The Alcohol Textbook; Jacques, K., Lyons, T., Keisall, D., Eds.; Nottingham University Press: Nottingham, UK, 2003; pp. 319-336.

59. Kirkels, A.F.; Verbong, G.P.J. Biomass gasification: Still promising? A 30-year global overview. Renew. Sustain. Energy Rev. 2011, 15, 471-481.

60. Matsumura, Y.; Minowa, T.; Potic, B.; Kersten, S.; Prins, W.; Vanswaaij, W.; Vandebeld, B.; Elliott, D.; Neuenschwander, G.; Kruse, A. Biomass gasification in near- and super-critical water: Status and prospects. Biomass Bioenergy 2005, 29, 269-292.

61. Babu, S. Thermal gasification of biomass technology developments: end of task report for 1992 to 1994. Biomass Bioenergy 1995, 9, 271-285.

62. Xu, D.; Tree, D.R.; Lewis, R.S. The effects of syngas impurities on syngas fermentation to liquid fuels. Biomass Bioenergy 2011, 35, 2690-2696.

63. Bronson, B.; Preto, F.; Mehrani, P. Effect of pretreatment on the physical properties of biomass and its relation to fluidized bed gasification. Environ. Prog. Sustain. Energy 2012, 31, 335-339.

64. Gómez, C.J.; Mészáros, E.; Jakab, E.; Velo, E.; Puigjaner, L. Thermogravimetry/mass spectrometry study of woody residues and an herbaceous biomass crop using PCA techniques. J. Anal. Appl. Pyrolysis 2007, 80, 416-426.

65. Mészáros, E.; Jakab, E.; Várhegyi, G.; Szepesváry, P.; Marosvölgyi, B. Comparative study of the thermal behavior of wood and bark of young shoots obtained from an energy plantation. J. Anal. Appl. Pyrolysis 2004, 72, 317-328.

66. Barneto, A.G.; Carmona, J.A.; Conesa, J.A. Effects of the composting and the heating rate on biomass gasification. Energy Fuels 2009, 23, 951-957. 
67. Barneto, A.G.; Ariza Carmona, J.; Díaz Blanco, M.J. Effect of the previous composting on volatiles production during biomass pyrolysis. J. Phys. Chem. A 2010, 114, 3756-3763.

68. Siedlecki, M.; de Jong, W.; Verkooijen, A.H.M. Fluidized bed gasification as a mature and reliable technology for the production of bio-syngas and applied in the production of liquid transportation fuels - a review. Energies 2011, 4, 389-434.

69. Herguido, J.; Corella, J.; Gonzalez-Saiz, J. Steam gasification of lignocellulosic residues in a fluidized bed at a small pilot scale. Effect of the type of feedstock. Ind. Eng. Chem. Res. 1992, 31, 1274-1282.

70. Lv, P.M.; Xiong, Z.H.; Chang, J.; Wu, C.Z.; Chen, Y.; Zhu, J.X. An experimental study on biomass air-steam gasification in a fluidized bed. Bioresour. Technol. 2004, 95, 95-101.

71. Jand, N.; Foscolo, P.U. Decomposition of wood particles in fluidized beds. Ind. Eng. Chem. Res. 2005, 44, 5079-5089.

72. Puig-Arnavat, M.; Bruno, J.C.; Coronas, A. Review and analysis of biomass gasification models. Renew. Sustain. Energy Rev. 2010, 14, 2841-2851.

73. Gómez-Barea, A.; Leckner, B. Modeling of biomass gasification in fluidized bed. Prog. Energy Combust. Sci. 2010, 36, 444-509.

74. Cetin, E.; Moghtaderi, B.; Gupta, R.; Wall, T. Influence of pyrolysis conditions on the structure and gasification reactivity of biomass chars. Fuel 2004, 83, 2139-2150.

75. Chopra, S.; Jain, A.K. A review of fixed bed gasification systems for biomass. Int. Comm. Agric. Eng. 2007, 9, 1-23.

76. Bui, T.; Loof, R.; Bhattacharya, S.C. Multi-stage reactor for thermal gasification of wood. Energy 1994, 19, 397-404.

77. Prins, M.J.; Ptasinski, K.J.; Janssen, F.J.J.G. More efficient biomass gasification via torrefaction. Energy 2006, 31, 3458-3470.

78. Hlína, M.; Hrabovský, M.; Kopecký, V.; Konrád, M.; Kavka, T.; Skoblja, S. Plasma gasification of wood and production of gas with low content of tar. Czech. J. Phys. 2006, 56, B1179-B1184.

79. Zhang, L.; Xu, C.; Champagne, P. Overview of recent advances in thermo-chemical conversion of biomass. Energy Convers. Manag. 2010, 51, 969-982.

80. Yoshida, T.; Oshima, Y.; Matsumura, Y. Gasification of biomass model compounds and real biomass in supercritical water. Biomass Bioenergy 2004, 26, 71-78.

81. Drake, H.L.; Gössner, A.S.; Daniel, S.L. Old acetogens, new light. Ann. N.Y. Acad. Sci. 2008, $1125,100-128$.

82. Ljungdahl, L.G.; Wood, H. Total synthesis of acetate from $\mathrm{CO}_{2}$ by heterotrophic bacteria. Ann. Rev. Microbial. 1969, 23, 515-538.

83. Wood, H.G. Life with $\mathrm{CO}$ or $\mathrm{CO}_{2}$ and $\mathrm{H}_{2}$ as a source of carbon and energy. FASEB J. 1991, 5 , $156-163$.

84. Ljungdahl, L.G. The autotrophic pathway of acetate synthesis in acetogenic bacteria. Ann. Rev. Microbial. 1986, 40, 415-450.

85. Ragsdale, S.W.; Pierce, E. Acetogenesis and the Wood-Ljungdahl pathway of $\mathrm{CO}_{2}$ fixation. Biochim. Biophys. Acta 2008, 1784, 1873-1898.

86. Ragsdale, S.W. Life with carbon monoxide. Crit. Rev. Biochem. Mol. Boil. 2004, 39, 165-195. 
87. Drake, H.L.; Küsel, K.; Matthies, C.; Wood, H.G.; Ljungdahl, L.G. Acetogenic Prokaryotes. In The Prokaryotes; Dworkin, M., Falkow, S., Rosenberg, E., Schleifer, K.-H., Stackebrandt, E., Eds.; Springer New York: New York, NY, USA, 2006; pp. 354-420.

88. Russell, M.J.; Martin, W. The rocky roots of the acetyl-CoA pathway. Trends biochem. Sci. 2004, 29, 358-363.

89. Schopf, W. Earth's Earliest Biosphere: Its Origin and Evolution; Princeton University Press: Princeton, NJ, USA, 1984; p. 610.

90. Ragsdale, S.W. The Eastern and Western branches of the Wood/Ljungdahl pathway: How the East and West were won. BioFactors 1997, 6, 3-11.

91. Köpke, M.; Held, C.; Hujer, S.; Liesegang, H.; Wiezer, A.; Wollherr, A.; Ehrenreich, A.; Liebl, W.; Gottschalk, G.; Dürre, P. Clostridium ljungdahlii represents a microbial production platform based on syngas. Proc. Natl. Acad. Sci. USA 2010, 107, 13087-13092.

92. Tracy, B.P.; Jones, S.W.; Fast, A.G.; Indurthi, D.C.; Papoutsakis, E.T. Clostridia: the importance of their exceptional substrate and metabolite diversity for biofuel and biorefinery applications. Curr. Opin. Biotechnol. 2012, 23, 364-381.

93. Bennett, G. The central metabolic pathway from acetyl-CoA to butyryl-CoA in Clostridium acetobutylicum. FEMS Microbiol. Rev. 1995, 17, 241-249.

94. Shanmugasundaram, T.; Wood, H.G. Interaction of ferredoxin with carbon monoxide dehydrogenase from Clostridium thermoaceticum. J. Boil. Chem. 1992, 267, 897-900.

95. Drake, H.L.; Hu, S.I.; Wood, H.G. Purification of carbon monoxide dehydrogenase, a nickel enzyme from Clostridium thermocaceticum. J. Boil. Chem. 1980, 255, 7174-7180.

96. Hu, P.; Bowen, S.H.; Lewis, R.S. A thermodynamic analysis of electron production during syngas fermentation. Bioresour. Technol. 2011, 102, 8071-8076.

97. Bennett, B.; Lemon, B.J.; Peters, J.W. Reversible carbon monoxide binding and inhibition at the active site of the Fe-only hydrogenase. Biochemistry 2000, 39, 7455-7460.

98. Greco, C.; Bruschi, M.; Heimdal, J.; Fantucci, P.; De Gioia, L.; Ryde, U. Structural insights into the active-ready form of [FeFe]-hydrogenase and mechanistic details of its inhibition by carbon monoxide. Inorg. Chem. 2007, 46, 7256-7258.

99. Matsumoto, T.; Kabe, R.; Nonaka, K.; Ando, T.; Yoon, K.S.; Nakai, H.; Ogo, S. Model study of CO inhibition of [NiFe]hydrogenase. Inorg. Chem. 2011, 50, 8902-8906.

100. Seravalli, J.; Zhao, S.; Ragsdale, S.W. Mechanism of transfer of the methyl group from (6S)-methyltetrahydrofolate to the corrinoid/iron-sulfur protein catalyzed by the methyltransferase from Clostridium thermoaceticum: a key step in the Wood-Ljungdahl pathway of acetyl-CoA synthesis. Biochemistry 1999, 38, 5728-5735.

101. Bruant, G.; Lévesque, M.J.; Peter, C.; Guiot, S.R.; Masson, L. Genomic analysis of carbon monoxide utilization and butanol production by Clostridium carboxidivorans strain P7. PLoS One 2010, 5, 1-12.

102. Poehlein, A.; Schmidt, S.; Kaster, A.K.; Goenrich, M.; Vollmers, J.; Thürmer, A.; Bertsch, J.; Schuchmann, K.; Voigt, B.; Hecker, M.; et al. An ancient pathway combining carbon dioxide fixation with the generation and utilization of a sodium ion gradient for ATP synthesis. PLoS One 2012, 7, e33439. 
103. Doukov, T.I.; Iverson, T.M.; Seravalli, J.; Ragsdale, S.W.; Drennan, C.L. A Ni-Fe-Cu center in a bifunctional carbon monoxide dehydrogenase/acetyl-CoA synthase. Science 2002, 298, 567-572.

104. Ragsdale, S.W. Nickel and the carbon cycle. J. Inorg. Biochem. 2007, 101, 1657-1666.

105. Ragsdale, S.W. Enzymology of the acetyl-CoA pathway of $\mathrm{CO}_{2}$ fixation. Crit. Rev. Biochem. Mol. Boil. 1991, 26, 261-300.

106. Ragsdale, S.W.; Yi, L.; Bender, G.; Gupta, N.; Kung, Y.; Yan, L.; Stich, T.A.; Doukov, T.; Leichert, L.; Jenkins, P.M.; et al. Redox, haem and CO in enzymatic catalysis and regulation. Biochem. Soc. Trans. 2012, 40, 501-507.

107. Müller, V. Energy conservation in acetogenic bacteria. Appl. Environ. Microbial. 2003, 69, 6345-6353.

108. Das, A.; Ljungdahl, L.G. Electron-transport system in acetogens. In Biochemistry and Physiology of Anaerobic Bacteria; Ljungdahl, L.G., Adams, M.M., Barton, L., Ferry, J.G., Johnson, M., Eds.; Springer Verlag: New York, NY, USA, 2002; pp. 191-204.

109. Gottwald, M.; Andreesen, J.R.; LeGall, J.; Ljungdahl, L.G. Presence of Cytochrome and Menaquinone in Clostridium formicoaceticum and Clostridium thermoaceticum. J. Bacterial. 1975, 122, 325-328.

110. Müller, V.; Imkamp, F.; Biegel, E.; Schmidt, S.; Dilling, S. Discovery of a ferredoxin:NAD ${ }^{+}$ oxidoreductase (Rnf) in Acetobacterium woodii: a novel potential coupling site in acetogens. Ann. N.Y. Acad. Sci. 2008, 1125, 137-146.

111. Biegel, E.; Schmidt, S.; González, J.M.; Müller, V. Biochemistry, evolution and physiological function of the Rnf complex, a novel ion-motive electron transport complex in prokaryotes. Cell. Mol. Life Sci. 2011, 68, 613-634.

112. Biegel, E.; Schmidt, S.; Müller, V. Genetic, immunological and biochemical evidence for a Rnf complex in the acetogen Acetobacterium woodii. Environ. Microbial. 2009, 11, 1438-1443.

113. Biegel, E.; Müller, V. Bacterial $\mathrm{Na}^{+}$-translocating ferredoxin:NAD ${ }^{+}$oxidoreductase. Proc. Natl. Acad. Sci. USA 2010, 107, 18138-18142.

114. Wohlfarth, G.; Diekert, G. Thermodynamics of methylenetetrahydrofolate reduction to methyltetrahydrofolate and its implications for the energy metabolism of homoacetogenic bacteria. Arch. Microbiol. 1991, 155, 378-381.

115. Wang, S.; Huang, H.; Moll, J.; Thauer, R.K. NADP ${ }^{+}$reduction with reduced ferredoxin and $\mathrm{NADP}^{+}$reduction with NADH are coupled via an electron-bifurcating enzyme complex in Clostridium kluyveri. J. Bacterial. 2010, 192, 5115-5123.

116. Li, F.; Hinderberger, J.; Seedorf, H.; Zhang, J.; Buckel, W.; Thauer, R.K. Coupled ferredoxin and crotonyl coenzyme A $(\mathrm{CoA})$ reduction with $\mathrm{NADH}$ catalyzed by the butyryl-CoA dehydrogenase/Etf complex from Clostridium kluyveri. J. Bacterial. 2008, 190, 843-850.

117. Buckel, W.; Thauer, R.K. Energy conservation via electron bifurcating ferredoxin reduction and proton $/ \mathrm{Na}^{+}$translocating ferredoxin oxidation. Biochim. Biophys. Acta 2012, in press.

118. Herrmann, G.; Jayamani, E.; Mai, G.; Buckel, W. Energy conservation via electron-transferring flavoprotein in anaerobic bacteria. J. Bacterial. 2008, 190, 784-791.

119. Schuchmann, K.; Mueller, V. A bacterial electron bifurcating hydrogenase. J. Boil. Chem. 2012, 287, 31165-31171. 
120. Schmidt, S.; Biegel, E.; Müller, V. The ins and outs of $\mathrm{Na}^{+}$bioenergetics in Acetobacterium woodii. Biochim. Biophys. Acta 2009, 1787, 691-696.

121. Meinecke, B.; Bertram, J.; Gottschalk, G. Purification and characterization of the pyruvate-ferredoxin oxidoreductase from Clostridium acetobutylicum. Arch. Microbiol. 1989, $152,244-250$.

122. Schlegel, K.; Leone, V.; Faraldo-Gómez, J.D.; Müller, V. Promiscuous archaeal ATP synthase concurrently coupled to $\mathrm{Na}^{+}$and $\mathrm{H}^{+}$translocation. Proc. Natl. Acad. Sci. USA 2012, 109, 947-952.

123. Odelson, D.A.; Breznak, J.A. Volatile Fatty Acid production by the hindgut microbiota of xylophagous termites. Appl. Environ. Microbial. 1983, 45, 1602-1613.

124. Tholen, A.; Brune, A. Localization and in situ activities of homoacetogenic bacteria in the highly compartmentalized hindgut of soil-feeding higher termites (Cubitermes spp.). Appl. Environ. Microbial. 1999, 65, 4497-505.

125. Drake, H.L. Acetogenesis, Acetogenic Bacteria, and the Acetyl-CoA "Wood/Ljungdahl" Pathway: Past and Current Perspectives. In Acetogenesis; Drake, H.L., Ed.; Chapman and Hall: New York, NY, USA, 1994; pp. 3-60.

126. Sim, J.H.; Kamaruddin, A.H.; Long, W.S.; Najafpour, G. Clostridium aceticum-A potential organism in catalyzing carbon monoxide to acetic acid: Application of response surface methodology. Enzyme Microb. Technol. 2007, 40, 1234-1243.

127. Wagner, F.S., Jr. Acetic Acid. Kirk-Othmer Encycl. Chem. Technol. 2002, 1, 115-136.

128. Global Industry Analysts Inc. Global Market for Acetic Acid to Reach 12.15 Million Tons by 2017, According to New Report by Global Industry Analysts, Inc. Available online: http://www.prweb.com/releases/acetic_acid_acetates/vinyl_acetate_monomer_PTA/prweb92427 31.htm (accessed on 12 July 2012).

129. Parekh, S.R.; Cheryan, M. Production of acetate by mutant strains of Clostridium thermoaceticum. Appl. Microbiol. Biotechnol. 1991, 36, 384-387.

130. Demler, M.; Weuster-Botz, D. Reaction engineering analysis of hydrogenotrophic production of acetic acid by Acetobacterium woodii. Biotechnol. Bioeng. 2011, 108, 470-474.

131. Fei, Q.; Chang, H.N.; Shang, L.; Choi, J.; Kim, N.; Kang, J. The effect of volatile fatty acids as a sole carbon source on lipid accumulation by Cryptococcus albidus for biodiesel production. Bioresour. Technol. 2011, 102, 2695-2701.

132. Jin, G.; Yang, F.; Hu, C.; Shen, H.; Zhao, Z.K. Enzyme-assisted extraction of lipids directly from the culture of the oleaginous yeast Rhodosporidium toruloides. Bioresour. Technol. 2012, 111, $378-382$.

133. Stephanopoulos, G. Bioprocess and Microbe Engineering for Total Carbon Utilization in Biofuel Production. U.S. Patent 0177564, 21 July 2011.

134. Wieringa, K.T. Over het verdwijnen van waterstof en koolzuur onder anaerobe voorwaarden. Antonie van Leeuwenhoek 1936, 3, 263-273.

135. Wieringa, K.T. The formation of acetic acid from carbon dioxide and hydrogen by anaerobic spore-forming bacteria. Antonie van Leeuwenhoek 1939, 6, 251-262.

136. Braun, M.; Mayer, F.; Gottschalk, G. Clostridium aceticum (Wieringa), a microorganism producing acetic acid from molecular hydrogen and carbon dioxide. Arch. Microbial. 1981, 128, 288-293. 
137. Adamse, A. New isolation of Clostridium aceticum (Wieringa). Antonie van Leeuwenhoek 1980, $46,523-531$.

138. Sim, J.H.; Kamaruddin, A.H. Optimization of acetic acid production from synthesis gas by chemolithotrophic bacterium-Clostridium aceticum using statistical approach. Bioresour. Technol. 2008, 99, 2724-2735.

139. Drake, H.L.; Daniel, S.L. Physiology of the thermophilic acetogen Moorella thermoacetica. Res. Microbiol. 2004, 155, 869-883.

140. Fontaine, F.E.; Peterson, W.H.; McCoy, E.; Johnson, M.J.; Ritter, G.J. A New Type of Glucose Fermentation by Clostridium thermoaceticum. J. Bacteriol. 1942, 43, 701-715.

141. Balk, M.; Weijma, J.; Friedrich, M.W.; Stams, A.J.M. Methanol utilization by a novel thermophilic homoacetogenic bacterium, Moorella mulderi sp. nov., isolated from a bioreactor. Arch. Microbial. 2003, 179, 315-320.

142. Sakai, S.; Nakashimada, Y.; Yoshimoto, H.; Watanabe, S.; Okada, H.; Nishio, N. Ethanol production from $\mathrm{H}_{2}$ and $\mathrm{CO}_{2}$ by a newly isolated thermophilic bacterium, Moorella sp. HUC22-1. Biotechnol. Lett. 2004, 26, 1607-1612.

143. Jiang, B.; Henstra, A.M.; Paulo, P.L.; Balk, M.; van Doesburg, W.; Stams, A.J.M. Atypical one-carbon metabolism of an acetogenic and hydrogenogenic Moorella thermoacetica strain. Arch. Microbial. 2009, 191, 123-131.

144. Pierce, E.; Xie, G.; Barabote, R.D.; Saunders, E.; Han, C.S.; Detter, J.C.; Richardson, P.; Brettin, T.S.; Das, A.; Ljungdahl, L.G.; et al. The complete genome sequence of Moorella thermoacetica (f. Clostridium thermoaceticum). Environ. Microbial. 2008, 10, 2550-2573.

145. Wiegel, J.; Carreira, L.H.; Garrison, R.; Rabek, N.E.; Ljungdahl, L.G. Calcium magnesium acetate (CMA) manufacture from glucose by fermentation with thermophilic homoacetogenic bacteria. In Calcium Magnesium Acetate; Wise, D.L., Lavendis, Y.A., Metghalchi, M., Eds.; Elsevier Science Publisher: Amsterdam, The Netherlands, 1991; pp. 359-418.

146. Reed, W.M.; Bogdan., M.E. Application of cell recycling to continuous fermentative acetic acid production. Biotech. Bioeng. Symp. 1985, 15, 641-647.

147. Balch, W.E.; Schoberth, S.; Tanner, R.S.; Wolfe, R.S. Acetobacterium, a New Genus of Hydrogen-Oxidizing, Carbon Dioxide-Reducing, Anaerobic Bacteria. Int. J. Syst. Bacteriol. 1977, 27, 355-361.

148. Buschhorn, H.; Dürre, P.; Gottschalk, G. Production and Utilization of Ethanol by the Homoacetogen Acetobacterium woodii. Appl. Environ. Microbial. 1989, 55, 1835-1840.

149. Imkamp, F.; Biegel, E.; Jayamani, E.; Buckel, W.; Müller, V. Dissection of the caffeate respiratory chain in the acetogen Acetobacterium woodii: identification of an Rnf-type NADH dehydrogenase as a potential coupling site. J. Bacterial. 2007, 189, 8145-8153.

150. Köpke, M.; Mihalcea, C.; Bromley, J.C.; Simpson, S.D. Fermentative production of ethanol from carbon monoxide. Curr. Opin. Biotechnol. 2011, 22, 320-305.

151. Barik, S.; Prieto, S.; Harrison, S.B.; Clausen, E.C.; Gaddy, J.L. Biological production of alcohols from coal through indirect liquefaction. Appl. Biochem. Biotechnol. 1988, 18, 363-378.

152. Tanner, R.S.; Miller, L.M.; Yang, D. Clostridium ljungdahlii sp. nov., an acetogenic species in clostridial rRNA homology group I. Int. J. Syst. Bacterial. 1993, 43, 232-236. 
153. Phillips, J.R.; Klasson, K.T.; Claussen, E.C.; Gaddy, J.L. Biological Production of Ethanol from Coal Synthesis Gas. Appl. Biochem. Biotechnol. 1993, 39, 559-571.

154. Huhnke, R.; Lewis, R.; Tanner, R. Isolation and Characterization of Novel Clostridial Species. U.S. Patent 7704723 B2, 27 April 2010.

155. Saxena, J.; Tanner, R.S. Effect of trace metals on ethanol production from synthesis gas by the ethanologenic acetogen, Clostridium ragsdalei. J. Ind. Microbial. Biotechnol. 2011, 38, 513-521.

156. Kundiyana, D.K.; Huhnke, R.L.; Wilkins, M.R. Effect of nutrient limitation and two-stage continuous fermentor design on productivities during "Clostridium ragsdalei" syngas fermentation. Bioresour. Technol. 2011, 102, 6058-6064.

157. Kundiyana, D.K.; Wilkins, M.R.; Maddipati, P.; Huhnke, R.L. Effect of temperature, pH and buffer presence on ethanol production from synthesis gas by "Clostridium ragsdalei". Bioresour. Technol. 2011, 102, 5794-5799.

158. Saxena, J.; Tanner, R.S. Optimization of a corn steep medium for production of ethanol from synthesis gas fermentation by Clostridium ragsdalei. World J. Microbial. Biotechnol. 2012, 28, 1553-1561.

159. Kundiyana, D.K.; Huhnke, R.L.; Wilkins, M.R. Syngas fermentation in a 100-L pilot scale fermentor: design and process considerations. J. Biosci. Bioeng. 2010, 109, 492-498.

160. Abrini, J.; Naveau, H.; Nyns, E.J. Clostridium autoethanogenum, sp. nov., an anaerobic bacterium that produces ethanol from carbon monoxide. Arch. Microbiol. 1994, 161, 345-351.

161. Abubackar, H.N.; Veiga, M.C.; Kennes, C. Biological conversion of carbon monoxide to ethanol: effect of $\mathrm{pH}$, gas pressure, reducing agent and yeast extract. Bioresour. Technol. 2012, $114,518-522$.

162. Cotter, J.L.; Chinn, M.S.; Grunden, A.M. Influence of process parameters on growth of Clostridium ljungdahlii and Clostridium autoethanogenum on synthesis gas. Enzyme Microb. Technol. 2009, 44, 281-288.

163. Guo, Y.; Xu, J.; Zhang, Y.; Xu, H.; Yuan, Z.; Li, D. Medium optimization for ethanol production with Clostridium autoethanogenum with carbon monoxide as sole carbon source. Bioresour. Technol. 2010, 101, 8784-8789.

164. Cotter, J.L.; Chinn, M.S.; Grunden, A.M. Ethanol and acetate production by Clostridium ljungdahlii and Clostridium autoethanogenum using resting cells. Bioprocess Biosyst. Eng. 2009, 32, 369-380.

165. Allen, T.D.; Caldwell, M.E.; Lawson, P.A.; Huhnke, R.L.; Tanner, R.S. Alkalibaculum bacchi gen. nov., sp. nov., a CO-oxidizing, ethanol-producing acetogen isolated from livestock-impacted soil. Int. J. Syst. Evol. Microbial. 2010, 60, 2483-2489.

166. Liu, K.; Atiyeh, H.K.; Tanner, R.S.; Wilkins, M.R.; Huhnke, R.L. Fermentative production of ethanol from syngas using novel moderately alkaliphilic strains of Alkalibaculum bacchi. Bioresour. Technol. 2012, 104, 336-341.

167. Köpke, M.; Noack, S.; Dürre, P. The Past, Present, and Future of Biofuels-Biobutanol as Promising Alternative. In Biofuel Production-Recent Developments and Prospects; dos Santos Bernades, M.A., Ed.; InTech: Rijeka, Croatia, 2011; pp. 451-486.

168. Dürre, P. Biobutanol: an attractive biofuel. Biotechnol. J. 2007, 2, 1525-1534. 
169. Jones, D.T.; Woods, D.R. Acetone-butanol fermentation revisited. Microbiolog. Rev. 1986, 50, 484-524.

170. Ni, Y.; Sun, Z. Recent progress on industrial fermentative production of acetone-butanol-ethanol by Clostridium acetobutylicum in China. Appl. Microbial. Biotechnol. 2009, 83, 415-423.

171. Green, E.M. Fermentative production of butanol-the industrial perspective. Curr. Opin. Biotechnol. 2011, 22, 337-343.

172. Liou, J.S.C.; Balkwill, D.L.; Drake, G.R.; Tanner, R.S. Clostridium carboxidivorans sp. nov., a solvent-producing clostridium isolated from an agricultural settling lagoon, and reclassification of the acetogen Clostridium scatologenes strain SL1 as Clostridium drakei sp. nov. Int. J. Syst. Evol. Microbial. 2005, 55, 2085-2091.

173. Paul, D.; Austin, F.W.; Arick, T.; Bridges, S.M.; Burgess, S.C.; Dandass, Y.S.; Lawrence, M.L. Genome sequence of the solvent-producing bacterium Clostridium carboxidivorans strain P7T. J. Bacterial. 2010, 192, 5554-5555.

174. Hemme, C.L.; Mouttaki, H.; Lee, Y.J.; Zhang, G.; Goodwin, L.; Lucas, S.; Copeland, A.; Lapidus, A.; Glavina del Rio, T.; Tice, H.; et al. Genome Announcement-Sequencing of Multiple Clostridia Genomes Related to Biomass Conversion and Biofuels Production. J. Bacterial. 2010, 192, 6494-6496.

175. Hurst, K.M.; Lewis, R.S. Carbon monoxide partial pressure effects on the metabolic process of syngas fermentation. Biochem. Eng. J. 2010, 48, 159-165.

176. Ukpong, M.N.; Atiyeh, H.K.; De Lorme, M.J.M.; Liu, K.; Zhu, X.; Tanner, R.S.; Wilkins, M.R.; Stevenson, B.S. Physiological response of Clostridium carboxidivorans during conversion of synthesis gas to solvents in a gas-fed bioreactor. Biotechnol. Bioeng. 2012, 109, 2720-2728.

177. Küsel, K.; Dorsch, T.; Acker, G.; Stackebrandt, E.; Drake, H.L. Clostridium scatologenes strain SL1 isolated as an acetogenic bacterium from acidic sediments. Int. J. Syst. Evol. Microbial. 2000, 50, 537-546.

178. Zeikus, J.G.; Lynd, L.H.; Thompson, T.E.; Krzycki, J.A.; Weimer, P.J.; Hegge, P.W. Isolation and characterization of a new, methylotrophic, acidogenic anaerobe, the marburg strain. Curr. Microbiol. 1980, 3, 381-386.

179. Worden, R.M.; Grethlein, A.J.; Jain, M.K.; Datta, R. Production of butanol and ethanol from synthesis gas via fermentation. Fuel 1991, 70, 615-619.

180. Lynd, L.; Kerby, R.; Zeikus, J.G. Carbon monoxide metabolism of the methylotrophic acidogen Butyribacterium methylotrophicum. J. Bacterial. 1982, 149, 255-263.

181. Grethlein, A.J.; Worden, R.M.; Jain, M.K.; Datta, R. Evidence for production of $n$-butanol from carbon monoxide by Butyribacterium methylotrophicum. J. Ferment. Bioeng. 1991, 72, 58-60.

182. DSMZ. DSM-3468. Available online: http:/www.dsmz.de/catalogues/details/culture/DSM3468.html (accessed on 20 August 2012).

183. Gaddy, J.L.; Clausen, W.C. Clostridium ljungdahlii, an Anaerobic Ethanol and Acetate Producing Microorganism. U.S. Patent 5173429, 22 December 1992.

184. Huhnke, R.; Lewis, R.; Tanner, R.S. Isolation and Characterization of Novel Clostridial Species. U.S. Patent 2008/0057554, 6 March 2008. 
185. Gaddy, J.; Arora, D.; Ko, C.; Phillips, J.; Basu, R.; Wikstrom, C.; Clausen, E. Methods for Increasing the Production of Ethanol from Microbial Fermentation. U.S. Patent 2012/0122173 A1, 17 May 2012.

186. Simpson, S.D.; Warner, I.L.; Fung, J.M.Y.; Köpke, M. Optimised fermentation media. U.S. Patent 20110294177, 1 December 2011.

187. Girbal, L.; Vasconcelos, I.; Saint-Amans, S.; Soucaille, P. How neutral red modified carbon and electron flow in Clostridium acetobutylicum grown in chemostat culture at neutral pH. FEMS Microbiol. Rev. 1995, 16, 151-162.

188. Panneerselvam, A.; Wilkins, M.R.; Delorme, M.J.M.; Atiyeh, H.K.; Huhnke, R.L. Effects of Various Reducing Agents on Syngas Fermentation by "Clostridium ragsdalei". American Society of Agricultural and Biological Engineers: St. Joseph, MI, USA, 2010; Volume 2, pp. 135-144.

189. Kundiyana, D.K.; Huhnke, R.L.; Maddipati, P.; Atiyeh, H.K.; Wilkins, M.R. Feasibility of incorporating cotton seed extract in Clostridium strain P11 fermentation medium during synthesis gas fermentation. Bioresour. Technol. 2010, 101, 9673-9680.

190. Ragsdale, S.W. Nickel-based Enzyme Systems. J. Biolog. Chem. 2009, 284, 18571-18575.

191. Grethlein, A.J.; Worden, R.M.; Jain, M.K.; Datta, R. Continuous production of mixed alcohols and acids from carbon monoxide. Appl. Biochem. Biotechnol. 1990, 24-25, 875-884.

192. Ungerman, A.J.; Heindel, T.J. Carbon monoxide mass transfer for syngas fermentation in a stirred tank reactor with dual impeller configurations. Biotechnol. Prog. 2007, 23, 613-620.

193. Munasinghe, P.C.; Khanal, S.K. Syngas fermentation to biofuel: evaluation of carbon monoxide mass transfer coefficient (kLa) in different reactor configurations. Biotechnol. Prog. 2010, 26, $1616-1621$.

194. Gaddy, J. Biological Production of Products from Waste Gases. U.S. Patent 6340581 B1, 22 January 2002.

195. Trevethick, S.; Bromley, J.; Simpson, S.; Khosla, V. Improved Fermentation of Gaseous Substrates. Patent WO 2011/028137 A1, 10 March 2011.

196. Tsai, S.P.; Datta, R.; Basu, R.; Yoon, S.H. Syngas Conversion System Using Asymmetric Membrane and Anaerobic Microorganism. U.S. Patent 2009/0215163 A1, 29 August 2009.

197. Tsai, S.P.; Datta, R.; Basu, R.; Yoon, S.H.; Robey, R. Modular Membrane Supported Bioreactor for Conversion of Syngas Components to Liquid Products. U.S. Patent 2009/0029434 A1, 29 January 2009.

198. Hickey, R.; Datta, R.; Tsai, S.-P.; Basu, R. Membrane Supported Bioreactor for Conversion of Syngas Components to Liquid Products. U.S. Patent 2011/0256597 A1, 20 October 2011.

199. Hickey, R.; Basu, R.; Datta, R.; Tsai, S. Method of Conversion of Syngas Using Microorganism on Hydrophilic Membrane. U.S. Patent 7923227, 12 April 2011.

200. Desai, R.P.; Papoutsakis, E.T. Antisense RNA strategies for metabolic engineering of Clostridium acetobutylicum. Appl. Environ. Microbial. 1999, 65, 936-945.

201. Tummala, S.B.; Welker, N.E.; Eleftherios, T. Development and Characterization of a Gene Expression Reporter System for Clostridium acetobutylicum ATCC 824. Appl. Environ. Microbial. 1999, 65, 3793-3799. 
202. Girbal, L.; Mortier-Barriere, I.; Raynaud, F.; Rouanet, C.; Croux, C.; Soucaille, P. Development of a sensitive gene expression reporter system and an inducible promoter-repressor system for Clostridium acetobutylicum. Appl. Environ. Microbiol. 2003, 69, 4985-4988.

203. Feustel, L.; Nakotte, S.; Durre, P. Characterization and development of two reporter gene systems for Clostridium acetobutylicum. Appl. Environ. Microbiol. 2004, 70, 798-803.

204. Cui, G.; Hong, W.; Zhang, J.; Li, W.; Feng, Y.; Liu, Y.; Cui, Q. Targeted gene engineering in Clostridium cellulolyticum $\mathrm{H} 10$ without methylation. J. Microbial. Methods 2012, 89, 201-208.

205. Girbal, L.; Mortier-barrière, I.; Rouanet, C.; Croux, C.; Mortier-barrie, I.; Soucaille, P. Development of a Sensitive Gene Expression Reporter System and an Inducible PromoterRepressor System for Clostridium acetobutylicum. Appl. Environ. Microbial. 2003, 69, 4985-4988.

206. Dong, H.; Tao, W.; Zhang, Y.; Li, Y. Development of an anhydrotetracycline-inducible gene expression system for solvent-producing Clostridium acetobutylicum: A useful tool for strain engineering. Metab. Eng. 2012, 14, 59-67.

207. Tracy, B.P.; Jones, S.W.; Papoutsakis, E.T. Inactivation of $\sigma \mathrm{E}$ and $\sigma \mathrm{G}$ in Clostridium acetobutylicum illuminates their roles in clostridial-cell-form biogenesis, granulose synthesis, solventogenesis, and spore morphogenesis. J. Bacterial. 2011, 193, 1414-1426.

208. Argyros, D.A.; Tripathi, S.; Barrett, T.F.; Rogers, S.R.; Feinberg, L.F.; Olson, D.G.; Foden, J.M.; Miller, B.B.; Lynd, L.R.; Hogsett, D.; et al. High ethanol titers from cellulose by using metabolically engineered thermophilic, anaerobic microbes. Appl. Environ. Microbial. 2011, 77, 8288-8294.

209. Tripathi, S.; Olson, D.G.; Argyros, D.A.; Miller, B.B.; Barrett, T.F.; Murphy, D.M.; McCool, J.D.; Warner, A.K.; Rajgarhia, V.B.; Lynd, L.R.; et al. Development of pyrF-based genetic system for targeted gene deletion in Clostridium thermocellum and creation of a pta mutant. Appl. Environ. Microbial. 2010, 76, 6591-6599.

210. Tracy, B.; Papoutsakis, E. Methods and Compositions for Genetically Engineering Clostridia Species. U.S. Patent 2010/0075424, 25 March 2010.

211. Cartman, S.; Minton, N. Method of Double Crossover Homologous Recombination in Clostridia. Patent WO/2010/084349, 29 July 2010.

212. Soucaille, P.; Figge, R.; Croux, C. Process for Chromosomal Integration and DNA Sequence Replacement in Clostridia. Patent WO/2008/040387, 10 April 2008.

213. Heap, J.T.; Pennington, O.J.; Cartman, S.T.; Carter, G.P.; Minton, N.P. The ClosTron: a universal gene knock-out system for the genus Clostridium. J. Microbiology. Methods 2007, 70, 452-464.

214. Heap, J.T.; Kuehne, S.; Ehsaan, M.; Cartman, S.T.; Cooksley, C.M.; Scott, J.C.; Minton, N.P. The ClosTron: Mutagenesis in Clostridium refined and streamlined. J. Microbiol. Methods 2010, $80,49-55$.

215. Kuehne, S.A.; Heap, J.T.; Cooksley, C.M.; Cartman, S.T.; Minton, N.P. ClosTron-mediated engineering of Clostridium. Methods Mol. Boil. 2011, 765, 389-407.

216. Heap, J.T.; Ehsaan, M.; Cooksley, C.M.; Ng, Y.K.; Cartman, S.T.; Winzer, K.; Minton, N.P. Integration of DNA into bacterial chromosomes from plasmids without a counter-selection marker. Nucleic Acids Res. 2012, 40, 1-10. 
217. Lütke-Eversloh, T.; Bahl, H. Metabolic engineering of Clostridium acetobutylicum: Recent advances to improve butanol production. Curr. Opin. Biotechnol. 2011, 22, 634-647.

218. William, J.R. Securities and Exchange Commission. Coskata, Inc.: Warrenville, IL, USA, Available online: http://www.sec.gov/Archives/edgar/data/1536893/000119312511343587/d267854ds1.htm (accessed on 9 July 2012).

219. Tirado-Acevedo, O. Production of Bioethanol from Synthesis Gas Using Clostridium ljungdahlii. Ph.D. Thesis, North Carolina State University, Raleigh, NC, USA, 17 November 2010.

220. Koepke, M.; Liew, F. Production of Butanol from Carbon Monoxide by a Recombinant Microorganism. Patent WO/2012/053905, 26 April 2012.

221. Lederle, S.M. Heterofermentative Acetonproduktion. Ph.D. Thesis, Ulm University, Ulm, Germany, 7 July 2010.

222. May, A.; Fischer, R.J.; Maria Thum, S.; Schaffer, S.; Verseck, S.; Dürre, P.; Bahl, H. A modified pathway for the production of acetone in Escherichia coli. Metab. Eng. 2012, in press.

223. Peralta-Yahya, P.P.; Zhang, F.; del Cardayre, S.B.; Keasling, J.D. Microbial engineering for the production of advanced biofuels. Nature 2012, 488, 320-328.

224. Trawick, J.D.; Burk, M.J.; Burgard, A.P. Microorganisms and Methods for Conversion of Syngas and Other Carbon Sources to Useful Products. Patent WO/2010/071697, 26 June 2010.

225. Burk, M.; Schilling, C.H.; Burgard, A.; Trawick, J.D. Methods and Organisms for Utilizing Synthesis Gas or Other Gaseous Carbon Sources and Methanol. Patent WO/2009/094485, 7 July 2009.

226. Papoutsakis, E.T.; Al-Hinai, M.A.; Jones, S.W.; Indurthi, D.C.; Mitchell, D.K.; Fast, A. Recombinant Clostridia That Fix CO2 and CO and Uses Thereof. U.S. Patent 2012/0064587 A1, 15 March 2012.

227. Kaster, A.K.; Goenrich, M.; Seedorf, H.; Liesegang, H.; Wollherr, A.; Gottschalk, G.; Thauer, R.K. More than 200 genes required for methane formation from $\mathrm{H}_{2}$ and $\mathrm{CO}_{2}$ and energy conservation are present in Methanothermobacter marburgensis and Methanothermobacter thermautotrophicus. Archaea 2011, $2011,973848$.

228. Roh, H.; Ko, H.J.; Kim, D.; Choi, D.G.; Park, S.; Kim, S.; Chang, I.S.; Choi, I.G. Complete Genome Sequence of a Carbon Monoxide-Utilizing Acetogen, Eubacterium limosum KIST612. J. Bacterial. 2011, 193, 307-308.

229. Elsevier B.V. SciVerse ${ }^{\circledR}$ Scopus ${ }^{\circledR}$. Available online: http://www.scopus.com (accessed on 20 July 2012).

230. Thomson Reuters. Thomson Innovation. Available online: http://thomsoninnovation.com (accessed on 20 July 2012).

231. Datar, R.P.; Shenkman, R.M.; Cateni, B.G.; Huhnke, R.L.; Lewis, R.S. Fermentation of biomass-generated producer gas to ethanol. Biotechnol. Bioeng. 2004, 86, 587-594.

232. Ahmed, A.; Lewis, R.S. Fermentation of biomass-generated synthesis gas: Effects of nitric oxide. Biotechnol. Bioeng. 2007, 97, 1080-1086.

233. Ahmed, A.; Cateni, B.G.; Huhnke, R.L.; Lewis, R.S. Effects of biomass-generated producer gas constituents on cell growth, product distribution and hydrogenase activity of Clostridium carboxidivorans P7T. Biomass Bioenergy 2006, 30, 665-672. 
234. Rabou, L.P. L.M.; Zwart, R.W.R.; Vreugdenhil, B.J.; Bos, L. Tar in Biomass Producer Gas, the Energy research Centre of the Netherlands (ECN) Experience: An Enduring Challenge. Energy Fuels 2009, 23, 6189-6198.

235. Brogren, C.; Karlsson, H.T.; Bjerle, I. Absorption of NO in an alkaline solution of $\mathrm{KMnO}_{4}$. Chem. Eng. Technol. 1997, 20, 396-402.

236. Chu, H.; Chien, T.W.; Li, S.Y. Simultaneous absorption of $\mathrm{SO}_{2}$ and $\mathrm{NO}$ from flue gas with $\mathrm{KMnO}_{4} / \mathrm{NaOH}$ solutions. Sci. Total Environ. 2001, 275, 127-135.

237. Sada, E.; Kumazawa, H.; Kudo, I.; Kondo, T. Absorption of NO in aqueous mixed solutions of $\mathrm{NaClO}_{2}$ and $\mathrm{NaOH}$. Chem. Eng. Sci. 1978, 33, 315-318.

238. Mojtahedi, W.; Ylitalo, M.; Maunula, T.; Abbasian, J. Catalytic decomposition of ammonia in fuel gas produced in pilot-scale pressurized fluidized-bed gasifier. Fuel Process. Technol. 1995, 45, 221-236.

239. Xu, C.C.; Donald, J.; Byambajav, E.; Ohtsuka, Y. Recent advances in catalysts for hot-gas removal of tar and $\mathrm{NH}_{3}$ from biomass gasification. Fuel 2010, 89, 1784-1795.

240. Grethlein, A.J.; Soni, B.K.; Worden, R.M.; Jain, M.K. Influence of hydrogen sulfide on the growth and metabolism of butyribacterium methylotrophicum and clostridium acetobutylicum. Appl. Biochem. Biotechnol. 1992, 34-35, 233-246.

241. Carpenter, D.L.; Bain, R.L.; Davis, R.E.; Dutta, A.; Feik, C.J.; Gaston, K.R.; Jablonski, W.; Phillips, S.D.; Nimlos, M.R. Pilot-Scale Gasification of Corn Stover, Switchgrass, Wheat Straw, and Wood: 1. Parametric Study and Comparison with Literature. Ind. Eng. Chem. Res. 2010, 49, 1859-1871.

242. Imlay, J. Iron-sulphur clusters and the problem with oxygen. Mol. Microbial. 2006, 59, 1073-1082.

243. Uyeda, K.; Rabinowitz, J.C. Pyruvate-ferredoxin oxidoreductase. IV. Studies on the reaction mechanism. J. Biol. Chem. 1971, 246, 3120-3125.

244. Karnholz, A.; Küsel, K.; Gössner, A.; Schramm, A.; Drake, H.L. Tolerance and metabolic response of acetogenic bacteria toward oxygen. Appl. Environ. Microbiol. 2002, 68, 1005-1009.

245. Kawasaki, S.; Watamura, Y.; Ono, M.; Watanabe, T.; Takeda, K.; Niimura, Y. Adaptive responses to oxygen stress in obligatory anaerobes Clostridium acetobutylicum and Clostridium aminovalericum. Appl. Environ. Microbiol. 2005, 71, 8442-8450.

246. Kawasaki, S.; Ishikura, J.; Watamura, Y.; Niimura, Y. Identification of $\mathrm{O}_{2}$-induced peptides in an obligatory anaerobe, Clostridium acetobutylicum. FEBS Lett. 2004, 571, 21-25.

247. McCord, J.M.; Keele, B.B.; Fridovich, I. An enzyme-based theory of obligate anaerobiosis: the physiological function of superoxide dismutase. Proc. Natl. Acad. Sci. USA 1971, 68, 1024-1027.

248. Zhu, L.; Dong, H.; Zhang, Y.; Li, Y. Engineering the robustness of Clostridium acetobutylicum by introducing glutathione biosynthetic capability. Metab. Eng. 2011, 13, 426-434.

249. Boerrigter, H.; Den Uil, H.; Calis, H.P. Green Diesel from Biomass via Fischer-Tropsch Synthesis: New Insights in Gas Cleaning and Process Design. In Proceedings of Pyrolysis and Gasification of Biomass and Waste, Expert Meeting; Strasbourg, France, 30 September-1 October 2002.

250. Qureshi, N.; Annous, B.A.; Ezeji, T.C.; Karcher, P.; Maddox, I.S. Biofilm reactors for industrial bioconversion processes: employing potential of enhanced reaction rates. Microb. Cell Fact. 2005, 4, 24. 
251. Tashiro, Y.; Takeda, K.; Kobayashi, G.; Sonomoto, K. High production of acetone-butanol-ethanol with high cell density culture by cell-recycling and bleeding. J. Biotechnol. 2005, 120, 197-206.

252. Klasson, K.; Ackerson, C.; Clausen, E.; Gaddy, J. Biological conversion of synthesis gas into fuels. Int. J. Hydrog. Energy 1992, 17, 281-288.

253. Jones, D.T. Bacteriophages of Clostridium. In Handbook on Clostridia; Dürre, P., Ed.; CRC Press: Boca Raton, FL, USA, 2005; pp. 699-719.

254. Jones, D.T.; Shirley, M.; Wu, X.; Keis, S. Bacteriophage infections in the industrial acetone butanol (AB) fermentation process. J. Mol. Microbiol. Biotechnol. 2000, 2, 21-26.

255. Vane, L.M. Separation technologies for the recovery and dehydration of alcohols from fermentation broths. Biofuels Bioprod. Biorefin. 2008, 2, 553-588.

256. Xiu, Z.L.; Zeng, A.P. Present state and perspective of downstream processing of biologically produced 1,3-propanediol and 2,3-butanediol. Appl. Microbiol. Biotechnol. 2008, 78, 917-926.

257. Gaddy, J.L. Clostridium strain which produces acetic acid from waste gases. U.S. Patent 5593886, 14 January 1997.

258. Gaddy, J.L. Biological production of acetic acid from waste gases with Clostridium ljungdahlii. U.S. Patent 5807722, 15 September 1998.

259. INEOS Bio. INEOS Bio: Advanced bioethanol production from ligno-cellulose residues and waste materials. Available online: http://www.biee.org/downloads/?dir=\&download=INEOS+Bio+ presentation+for+EI+April+2011.pdf (accessed on 22 July 2012).

260. Klasson, K.T.; Elmore, B.B.; Vega, J.L.; Ackerson, M.D.; Clausen, E.C.; Gaddy, J.L. Biological production of liquid and gaseous fuels from synthesis gas. Appl. Biochem. Biotechnol. 1990, 24-25, 857-873.

261. INEOS. Cars to run on fuel from household waste within two years. Available online: $\mathrm{http} / / /$ www.ineos.com/new_item.php?id_press=223 (accessed on 22 July 2012).

262. Wald, M. Yet Another Route to Cellulosic Ethanol. Available online: http://nyti.ms/POnkOJ (accessed on 16 July 2012).

263. Williams, P. Ineos Bio Takes Advanced Biofuel Technology Commercial. Available online: http://biomassmagazine.com/articles/6841/ineos-bio-takes-advanced-biofuel-technology-commercial (accessed on 16 July 2012).

264. INEOS Bio. INEOS Bio JV Breaks Ground on 1st Advanced Waste-to-Fuel Commercial Biorefinery in U.S. Available online: http://www.ineosbio.com/76-Press_releases-15.htm (accessed on 16 July 2012).

265. INEOS Bio. INEOS Bio Names AMEC as its Global License Support Engineering Firm for its Waste-to-Bioenergy Technology. Available online: http://www.ineosbio.com/76-Press_releases33.htm (accessed on 16 July 2012).

266. U.S. Department of Energy. INEOS Bio Commercializes bioenergy technology in Florida. Available online: http://www1.eere.energy.gov/biomass/pdfs/ibr_arraprojects_ineos.pdf (accessed on 1 August 2012).

267. INEOS Bio. Pioneering waste-to-biofuel technology attracts cross-Party support in UK. Available online: http://www.ineosbio.com/76-Press_releases-16.htm (accessed on 16 July 2012).

268. Zahn, J.A.; Saxena, J. Novel Ethanologenic Species Clostridium Coskatii. U.S. Patent 2011/0229947 A1, 22 September 2011. 
269. Coskata Inc Coskata, Inc.'s Semi-Commercial Facility Demonstrates Two Years of Successful Operation. Available online: http://www.coskata.com/company/media.asp?story=504B571C0916-474E-BFFA-ACB326EFDB68 (accessed on 23 July 2012).

270. Lane, J. Coskata switches focus from biomass to natural gas; to raise $\$ 100 \mathrm{M}$ in natgas-oriented private placement. Available online: http:/www.biofuelsdigest.com/bdigest/2012/07/20/ coskata-switches-from-biomass-to-natural-gas-to-raise-100m-in-natgas-oriented-private-placement/ (accessed on 23 July 2012).

271. Heijstra, B.; Kern, E.; Koepke, M.; Segovia, S.; Liew, F. Novel bacteria and methods of use thereof. Patent WO/2012/015317, 2 February 2012.

272. LanzaTech. INVISTA and LanzaTech Sign Joint Development Agreement for Bio-Based Butadiene. Available online: http:/www.lanzatech.com/sites/default/files/imce_uploads/ news_release_-_invista_announces_lanzatech_partnership_-_embargoed_final_0.pdf (accessed on 25 August 2012).

273. LanzaTech. LanzaTech's commercialisation goes transtasman. Available online: http://www.lanzatech.co.nz/sites/default/files/imce_uploads/lanzatech_signs_with_bluescope_ste el_march_2012.pdf (accessed on 23 July 2012).

274. Herndon, A. Range Fuels Sells Government-Backed Biofuel Plant To LanzaTech. Available online: http://www.bloomberg.com/news/2012-01-04/range-fuels-sells-governmentbacked-biofuel-plant-to-lanzatech.html (accessed on 23 July 2012).

(C) 2012 by the authors; licensee MDPI, Basel, Switzerland. This article is an open access article distributed under the terms and conditions of the Creative Commons Attribution license (http://creativecommons.org/licenses/by/3.0/). 